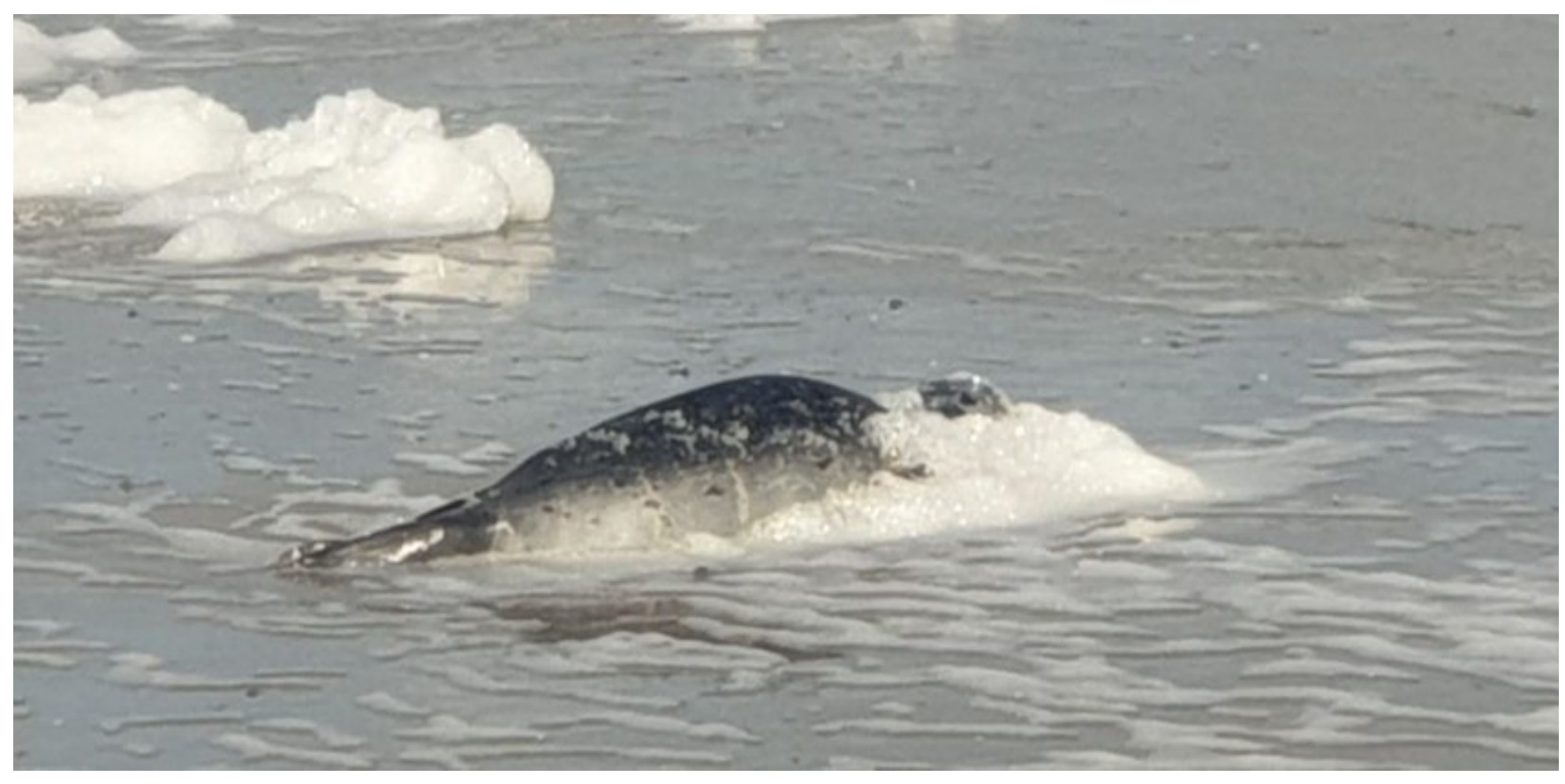

\title{
MSC ZOE: mogelijke effecten van de verloren containers op zeehonden
}




\section{MSC ZOE: mogelijke effecten van de verloren containers op zeehonden}

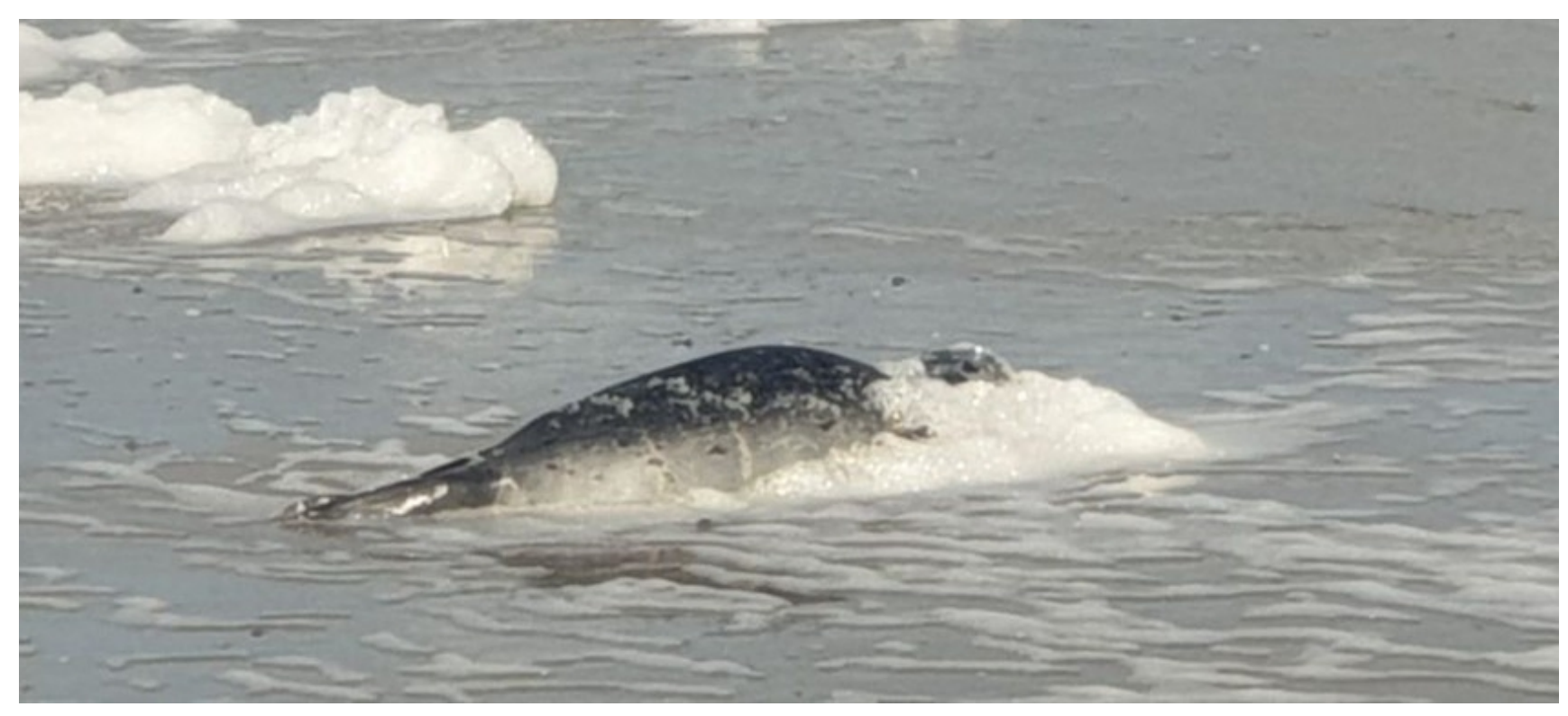


Dit onderzoek is uitgevoerd door Wageningen Marine Research in opdracht van en gefinancierd door het Ministerie van Landbouw, Natuur en Voedselkwaliteit, in het kader van het Beleidsondersteunend onderzoekthema (projectnummer BO43-023.02-039-WMR)

Wageningen Marine Research

Den Helder, mei 2020

VERTROUWELIJK Nee

Wageningen Marine Research rapport C043/20

\section{(c) Wageningen Marine Research}

Wageningen Marine Research, instituut binnen de rechtspersoon Stichting Wageningen Research, hierbij vertegenwoordigt door Dr. M.C.Th. Scholten, Algemeen directeur

KvK nr. 09098104,

WMR BTW nr. NL 8113.83.696.B16.

Code BIC/SWIFT address: RABONL2U

IBAN code: NL 73 RABO 0373599285
Wageningen Marine Research aanvaardt geen aansprakelijkheid voor gevolgschade, noch voor schade welke voortvloeit uit toepassingen van de resultaten van werkzaamheden of andere gegevens verkregen van Wageningen Marine Research opdrachtgever vrijwaart Wageningen Marine Research van aanspraken van derden in verband met deze toepassing.

Alle rechten voorbehouden. Niets uit deze uitgave mag weergegeven en/of gepubliceerd worden, gefotokopieerd of op enige andere manier gebruikt worden zonder schriftelijke toestemming van de uitgever of auteur. 
Keywords: MSC ZOE, zeehonden, plastic.

Opdrachtgever: Ministerie van LNV

T.a.v.: Karst Jaarsma en Bram Streefland

Bezuidenhoutseweg 73

2594 AC Den Haag

BAS code: 4318100287

Dit rapport is gratis te downloaden van https://doi.org/10.18174/521148

Wageningen Marine Research verstrekt geen gedrukte exemplaren van rapporten.

Wageningen Marine Research is ISO 9001:2015 gecertificeerd.

Foto omslag: Rob Knoeff 


\section{Dankwoord}

Om dode wilde dieren te verzamelen is er een samenwerking nodig. Soms met instituten, maar vaak ook met vrijwilligers die ter plaatse zijn. Zonder deze samenwerking had dit document niet tot stand kunnen komen. Wij bedanken diversen netwerken waaronder RTZ (Stichting Reddingsteam Zeedieren) Jaap van de Hiele, Rob Knoeff van de dierenambulance Ameland, EHBZ (Eerste Hulp Bij Zeehonden) Michael Bakker Paiva, Guus Schweigmann van Zeehondenopvang Terschelling, en de mensen van de waterpolitie. Ook bedanken wij de bemanningsleden van de Harder en de Krukel (Wadden Unit) om te letten op dode dieren in het water, en de mensen van Natuurmonumenten en Staatsbosbeheer om (ook) op de onbewoonde eilanden een oogje in het zeil te houden.

Van de Universiteit Utrecht bedanken we Lonneke IJsseldijk voor haar inzet, en het personeel dat betrokken was bij de necropsies. Verder bedanken wij Arnold Bakker en Maarten van Hoppe voor het verwerken van de magen en darmen in het lab, en Suse Kühn voor het meedenken met het project.

(C) Wageningen Marine Research

Wageningen Marine Research, instituut binnen de rechtspersoon Stichting Wageningen Research, hierbij vertegenwoordigt door Dr. M.C.Th. Scholten, Algemeen directeur

KvK nr. 09098104,

WMR BTW nr. NL 8113.83.696.B16.

Code BIC/SWIFT address: RABONL2U

IBAN code: NL 73 RABO 0373599285
Wageningen Marine Research aanvaardt geen aansprakelijkheid voor gevolgschade, noch voor schade welke voortvloeit uit toepassingen van de resultaten van werkzaamheden of andere gegevens verkregen van Wageningen Marine Research opdrachtgever vrijwaart Wageningen Marine Research van aanspraken van derden in verband met deze toepassing.

Alle rechten voorbehouden. Niets uit deze uitgave mag weergegeven en/of gepubliceerd worden, gefotokopieerd of op enige andere manier gebruikt worden zonder schriftelijke toestemming van de uitgever of auteur. 


\section{Inhoud}

$\begin{array}{lr}\text { Samenvatting } & 6\end{array}$

$\begin{array}{llr}1 & \text { Inleiding } & 7\end{array}$

$\begin{array}{lll}1.1 & \text { Aanleiding } & 7\end{array}$

1.2 Opdracht en vraagstelling $\quad 8$

2 Methoden $r$

$\begin{array}{lll}2.1 & \text { Analyse gestrande zeehonden } & 10\end{array}$

2.2 Dode zeehonden verzamelen vanuit het impact gebied 10

\begin{tabular}{ll}
2.3 & Pathologisch onderzoek \\
\hline
\end{tabular}

$\begin{array}{ll}2.4 & \text { Analyse van maag en darminhoud } \\ \end{array}$

2.4.1 Plastic analyse $\quad 13$

$\begin{array}{ll}2.4 .2 & \text { Dieet analyse }\end{array}$

$\begin{array}{llr}3 & \text { Resultaten } & 15\end{array}$

3.1 Strandingen van dode zeezoogdieren vanaf januari-2013-2018 en $2019 \quad 15$

3.2 Doodsoorzaken van vijftien gestrande zeehonden 16

$\begin{array}{ll}3.3 & \text { Maaginhoud } \\ & 3.3 .17\end{array}$

$\begin{array}{lll}3.3 .1 & \text { Plastics } & 17\end{array}$

$\begin{array}{lll}3.3 .2 & \text { Dieet } & 17\end{array}$

4 Discussie $r \begin{aligned} & 19\end{aligned}$

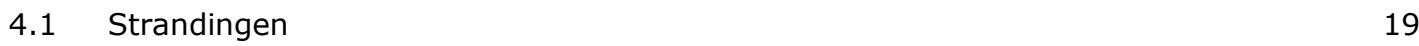

\begin{tabular}{ll}
4.2 & Pathologisch onderzoek \\
\hline
\end{tabular}

$\begin{array}{lll}4.3 & \text { Maag- en darmanalyse } & 20\end{array}$

$\begin{array}{lll}\text { 4.3.1 Aanwezigheid van plastic } & 21\end{array}$

$\begin{array}{lll}\text { 4.3.2 } & \text { Relatie tussen dieet en plastic } & 21\end{array}$

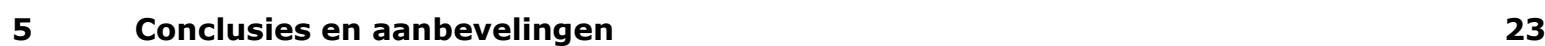

$\begin{array}{llr}6 & \text { Kwaliteitsborging } & 24\end{array}$

$\begin{array}{lr}\text { Literatuur } & 25\end{array}$

$\begin{array}{lr}\text { Verantwoording } & 28\end{array}$

$\begin{array}{llr}\text { Bijlage } 1 & \text { Foto's gestrande zeehonden } & 29\end{array}$ 


\section{Samenvatting}

Begin januari 2019 heeft het containerschip MSC ZOE door een storm meer dan 300 containers verloren ten noorden van de Waddeneilanden. De verloren containers waren beladen met een variatie aan goederen, waaronder ook plastic onderdelen en plastic pellets (basismateriaal voor de plasticindustrie). Om een eerste indruk te krijgen van mogelijk overlast die zeehonden kunnen hebben ondervonden van de verloren lading, is de doodsoorzaak en het verteringsstelsel van vijftien dood aangespoelde zeehonden onderzocht. Ook is er gekeken naar de geregistreerde strandingen van dode dieren in Noord-Nederland, door Ecomare, EHBZ en RTZ. Het aantal gemelde strandingen van dode gewone en grijze zeehonden is toegenomen in 2019, het jaar na het incident met de MSC ZOE. De strandingsgegevens worden niet nationaal beheerd waardoor er fouten, zoals duplicaten en inconsequente leeftijdscategorieën zijn toegewezen. Daarnaast is in deze strandingsgegevens geen correctie voor de groei van de zeehondenpopulatie toegepast.

Twee van de vijftien zeehonden zijn waarschijnlijk omgekomen doordat deze in aanraking gekomen zijn met een voorwerp in het water. Of het een voorwerp betreft dat afkomstig is geweest van de MSC ZOE, was niet te achterhalen. Daarnaast kan, door het ontbreken van een monitoringsprogramma, niet achterhaald worden of de sterfte van zeehonden verhoogd is ten opzichte van voor het incident. In het verteringsstelsel van de zeehonden zijn geen plastics aangetroffen die direct of via hun dieet zijn binnengekomen. Van de vissoorten, waarvan resten gevonden zijn in de magen en darmen, is in literatuur te vinden dat daar plastics kunnen worden aangetroffen.

Op basis van deze gegevens is geen indicatie gevonden dat zeehonden overlast hebben ondervonden van de verloren lading van de MSC ZOE. Daarbij moeten drie kanttekeningen gemaakt worden: 1 ) Vijftien zeehonden is een te laag aantal om harde conclusies aan te verbinden. 2) Een nationaal gecontroleerd en gemanaged registratiesysteem voor dode zeehonden ontbreekt, en het is voor deze maar ook voor volgende projecten raadzaam om hierin te investeren. 3) Door het ontbreken van een monitoringsprogramma voor het achterhalen van de doodsoorzaak van overleden zeehonden en het bekijken van de hoeveelheid plastics, is niet te zeggen of de bevindingen afwijken van normaal. 


\section{$1 \quad$ Inleiding}

\section{$1.1 \quad$ Aanleiding}

In de nacht van 1 op 2 januari 2019 verloor het vrachtschip MSC ZOE circa 345 containers tijdens een noordwesterstorm. Het schip, met een laadcapaciteit van 19.000 containers, was beladen met ongeveer 8000 containers en was onderweg van Sines in Portugal naar Bremerhaven in Duitsland. De containers zijn ten noorden van de Nederlandse Waddenzee overboord geslagen. In dit rapport wordt besproken hoe dit mogelijk de zeehondenpopulatie heeft geraakt en aan de hand van een relatief klein monster van vijftien gestrande zeehonden een eerste indruk gegeven van mogelijk aanwezigheid van kunststoffen in het verteringsstelsel van zeehonden afkomstig uit de verloren containers.

Er zijn achttien containers aangespoeld langs de Nederlandse kusten, het merendeel is echter op de zeebodem terecht gekomen. In totaal zijn 295 containers geborgen en is er $2.360 .000 \mathrm{~kg}$ van de $3.200 .000 \mathrm{~kg}$ verloren lading geborgen. Luchtfoto's genomen op 3 januari, tijdens een grijze zeehonden telling, laten duidelijk zien dat langs de kust van Terschelling, maar ook Schiermonnikoog en de zandbanken ten oosten ervan, veel objecten zijn aangespoeld. De containers waren geladen met een grote variatie aan goederen: waaronder diverse auto-onderdelen, handtassen, vriezers, stoeltjes, schoenen, zeeppompjes, speelgoed, flat screen-tv's, ledlampen, matrassen, stofzuigerslangen en compressors. In de lading bevonden zich ook pellets en korrels die als grondstof gebruikt worden in de plasticindustrie. Een compleet overzicht van de verloren lading is te vinden op:

https://www.rijksoverheid.nl/documenten/wob-verZOEken/2019/05/09/besluit-wob-verZOEk-ladingmsc-ZOE.

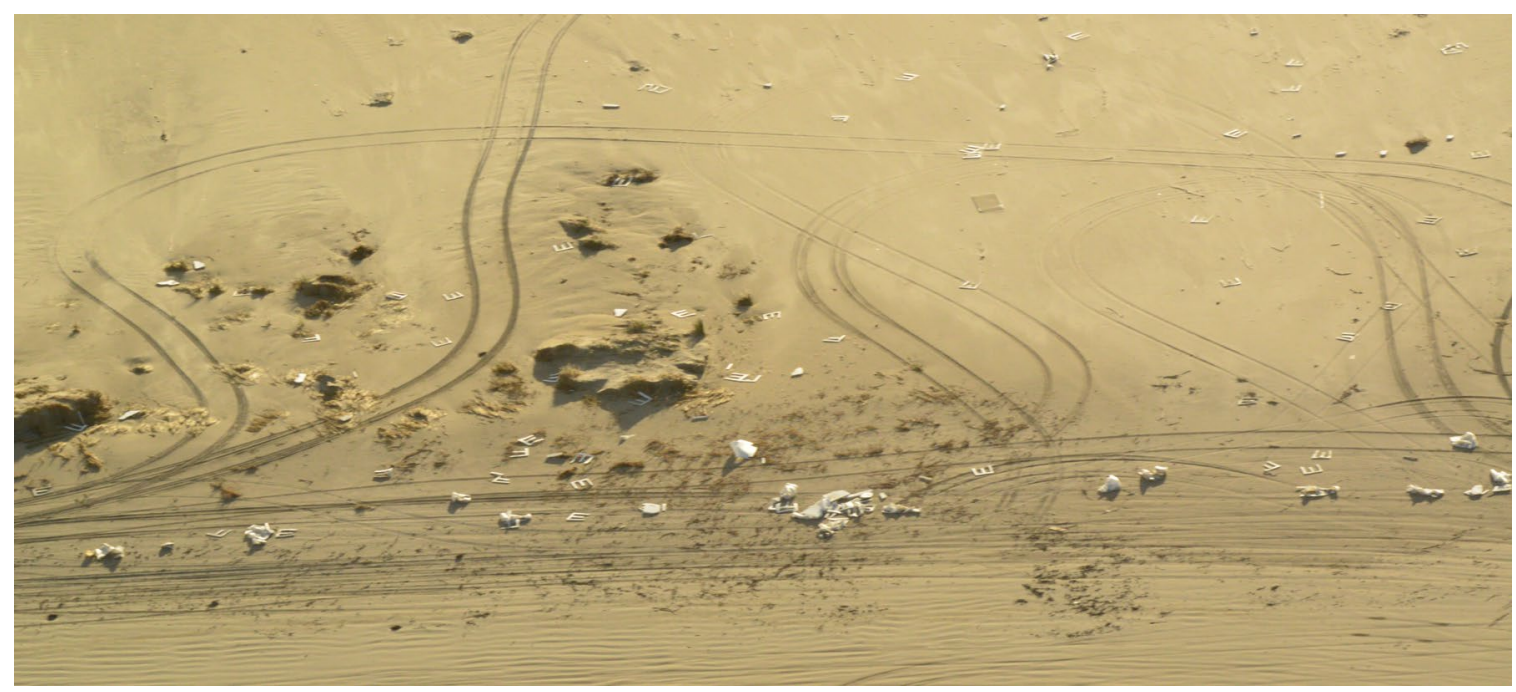

Figuur 1 Aangespoeld afval samen met autosporen langs de kust van Terschelling. De foto is 3 januari 2019 genomen vanuit het vliegtuig tijdens de monitoring van grijze zeehonden pups.

Omdat plastics slecht in het milieu afbreken, is er zorg bij verschillende natuurorganisaties dat vooral dit deel van de lading negatieve ecologische gevolgen kan veroorzaken. Op verschillende publieke forums werd ook de angst uitgesproken dat de verloren lading de overleving van zeehonden zou beïnvloeden. Menselijk afval wordt overal ter wereld aangetroffen, en vooral plastic wordt in het marine milieu gemonitord (Shomura and Yoshida 1985; Derraik 2002). Zeeorganismen kunnen last krijgen van dit plastic, door verstrikking, of door inname. Bij inname zijn directe gevolgen te verwachten wanneer het verteringsstelsel door het plastic beschadigd of verstopt raakt (Browne et al. 2015). Ook zouden afbraakproducten van plastics of stoffen die aan plastics hechten indirect de organismen negatief kunnen beïnvloeden. Daarnaast zullen grotere plastic objecten (zogenaamde macroplastics, > $5 \mathrm{~mm}$ ), na verloop van tijd slijten en uiteenvallen, en vervolgens bijdragen tot de 
totale hoeveelheid zogenaamde microplastics (stukjes $<5 \mathrm{~mm}$ ) in zee. Het aantal soorten zeedieren waarbij plastic gerapporteerd werd (in het verteringsstelsel of waarin dieren verstrikt zijn) neemt toe. Tussen 1997 en 2015 was de toename van 267 (Laist 1997) tot 557 soorten (Kühn, Bravo Rebolledo, and Van Franeker 2015). Dit geldt ook voor het aantal zeezoogdiersoorten met plastic: tussen 1997 en 2015 is het aantal soorten waarbij plastic werd gerapporteerd gestegen van 81 tot 86 van de 123 zeezoogdiersoorten (Kühn, Bravo Rebolledo, and Van Franeker 2015; Kühn and Van Franeker 2020). Bij de 86 zeezoogdiersoorten hadden $56 \%$ soorten plastics had ingeslikt en was $40 \%$ verstrikt (Kühn and Van Franeker 2020).

Het was al vroeg duidelijk dat zeezoogdieren in (plastic)afval verstrikt kunnen raken (Fowler 1988). Zeezoogdieren blijken echter ook, net als de andere mariene organismen, plastic binnen te krijgen, omdat ze dit zien als een potentiële prooi, of omdat de prooi die ze vangen plastics heeft gegeten. In verhouding tot andere soorten foerageren zeezoogdieren op een relatief hoog trofisch niveau, bovendien hebben ze een relatief hoge levensverwachting. Hierdoor is er een verhoogde kans op bioaccumulatie en biomagnificatie van in plastic opgeloste stoffen (Jepson et al. 2016; Pierce et al. 2008). De schadelijke stoffen kunnen in de loop van de tijd in de dieren ophopen en potentieel hun gezondheid beïnvloeden. Om deze reden kan het onderzoeken van de gezondheid van zeezoogdieren indicatief zijn voor de volksgezondheid vooral als het gaat om consumptie van mariene producten zoals vis (Bossart 2011).

Door de toename van plastics in de omgeving, zoals door de MSC ZOE verloren (micro)plastics, wordt de kans groter dat meer zeezoogdieren hiermee in aanraking komen. De dieren kunnen hier mee te maken krijgen door directe inname of indirect via de prooien. Het is mogelijk dat de plastic vervuiling uiteindelijk impact zal hebben op de gezondheid, het foerageersucces, de groei en de overleving van met name de vele zeehonden die permanent in het gebied leven. Er is relatief weinig onderzoek gedaan naar plastics bij zeehondenachtigen (pinnipedia), toch blijkt dat ook bij deze groep plastic wordt aangetroffen, ook bij de twee soorten die in het waddengebied voorkomt: grijze zeehond (Halichoerus grypus) en gewone zeehond (Phoca vitulina) (Tabel 1). Omdat zeehonden het plastic voor een belangrijk deel tijdens het foerageren binnenkrijgen, is het een essentiële stap om dieetonderzoek uit te voeren. Hiermee wordt inzichtelijk gemaakt welke prooisoorten de kans op inname/aanwezigheid van plastics verhogen.

Tabel 1 Beperkt aantal studies is uitgevoerd waarbij plastic inname door grijze en gewone zeehonden onderzocht is (Kühn and Van Franeker 2020).

\begin{tabular}{lcccl}
$\begin{array}{l}\text { Soort naam } \\
\text { Grijze } \\
\text { zeehond }\end{array}$ & $\begin{array}{c}\text { Aantal individuen } \\
\text { onderzocht }\end{array}$ & $\begin{array}{c}\text { Aantal individuen } \\
\text { met plastic }\end{array}$ & $\begin{array}{c}\text { Individuen met } \\
\text { plastic (\%) }\end{array}$ & \multicolumn{1}{c}{ Aantal bronnen } \\
\hline $\begin{array}{l}\text { Gewone } \\
\text { zeehond }\end{array}$ & 126 & 6 & $5 \%$ & $\begin{array}{l}\text { 2: (Nelms et al. 2019; Osinga } \\
2006)\end{array}$ \\
\hline
\end{tabular}

\subsection{Opdracht en vraagstelling}

Het ministerie van Landbouw, Natuur en Voedselkwaliteit (LNV) gaf begin 2019 opdracht om mogelijke effecten op de omgeving van het verliezen van containers te onderzoeken, zo ook op zeezoogdieren. In de Nederlandse Noordzee en Waddenzee leven verschillen soorten zeezoogdieren, waaronder de gewone zeehond, de grijze zeehond en de bruinvis (Phocoena phocoena). Voor dit onderzoek is overeengekomen om gedurende het jaar volgend op de ramp (2019) zeezoogdieren uit het potentiële impact gebied te verzamelen en hiervan de doodsoorzaak te achterhalen en te onderzoeken of in de maag en darm resten te vinden zijn die in relatie gebracht kunnen worden met de verloren lading. In dit rapport is de focus gelegd op het inzamelen van gewone en grijze zeehonden, de meest voorkomende zeezoogdiersoorten in de Waddenzee. Het werk dat uitgevoerd werd in het kader van dit 
project zal tevens dienen om een referentiecollectie aan te leggen van doodsoorzaken van zeehonden met hierbij horende maag en darm onderzoek.

Om de mogelijke impact van de verloren MSC ZOE containers en inhoud hiervan te bepalen de volgende hoofdvraag met de bijhorende sub-vragen gedefinieerd:

Hebben gewone en grijze zeehonden hinder ondervonden van het incident waarbij de MSC ZOE geladen containers verloor in begin 2019 ?

1. Is er een toename in het aantal strandingen van zeehonden langs de Noord-Nederlandse kusten?

2. Waar zijn vijftien verzamelde zeehonden aan doodgegaan?

3. Zijn er plastics gevonden in het verteringstelsel van de vijftien verzamelde zeehonden? i) Wat voor plastics zijn dit?

ii) Kunnen deze plastics afkomstig zijn van de verloren lading van de MSC ZOE?

iii) Is er een relatie te vinden tussen het plastic en de prooisoorten? 


\section{$2 \quad$ Methoden}

Voor het beantwoorden van de gestelde vragen zijn verschillende bronnen geraadpleegd. Voor het aantal strandingen is gebruik gemaakt van data uit Waarneming.nl. De mogelijke doodsoorzaak werd achterhaald door autopsies uitgevoerd door Veterinair Pathologisch Diagnostisch Centrum (VPDC) van het Departement Pathobiologie, Faculteit Diergeneeskunde, Universiteit Utrecht. De analyse van strandingen, plastics, dieet werd uitgevoerd door onderzoekers van Wageningen Marine Research.

\subsection{Analyse gestrande zeehonden}

Door het ontbreken van een structurele registratie van gestrande zeehonden langs de Nederlandse kusten, is gebruik gemaakt van een alternatief: Waarneming.nl. Op deze website kan iedereen vrijwillig observaties in de natuur melden. Hoewel de site wordt bijgehouden en geredigeerd, wordt er nagenoeg geen data check gedaan, waardoor het niet is uit te sluiten dat er dubbelmeldingen, foute determinaties en onvolledigheden in de dataset zijn (Brasseur 2018).

Voor dit onderzoek is gekozen om uit de gegevens van Waarneming.nl alleen de data van drie bronnen te gebruiken welke regelmatig melden en hun eigen registratie controleren: Ecomare, EHBZ (Eerste Hulp Bij Zeezoogdieren) en RTZ (Stichting Reddingsteam Zeedieren). Hierbij wordt aangenomen dat deze een groot deel van de dode dieren melden waarbij gedupliceerde meldingen minimaal zijn. Dit onderzoek richt zich op de periode vanaf 2013 tot en met 2019 en beperkt zich tot het noorden van Nederland; tussen lengtegraad van 4.5 tot 7.5 Oost en een breedtegraad van 52.8 tot 53.7 Noord. Binnen dit gebied is er onderscheid gemaakt tussen de bewoonde Waddeneilanden en alle overige gebieden. Bij de analyse is gekeken naar de verhouding tussen de verschillende leeftijdscategorieën: juveniel (jong), adult (volwassen), sub-adult (jongvolwassen) en onbekend. De overzichten beschrijven de aantallen dood gestrande zeehonden per jaar en of er een (extra) toename te zien is in het jaar na het verlies van containers van de MSC ZOE: 2019.

\subsection{Dode zeehonden verzamelen vanuit het impact gebied}

In 2019 zijn vijftien zeehonden verzameld langs de Waddenzeekust en rondom de Waddeneilanden (Figuur 2). De zeehonden zijn verzameld in de gebieden die overeenkomen met de vondsten van de meeste MSC ZOE afkomstige objecten in begin 2019 (ER rapportage tot en met 14 april 2019 MSc ZOE UPDATE 9.docx) (Figuur 3). Ook werden dode zeehonden direct uit de Waddenzee verzameld (zeehond nr. 1 en nr. 4). 


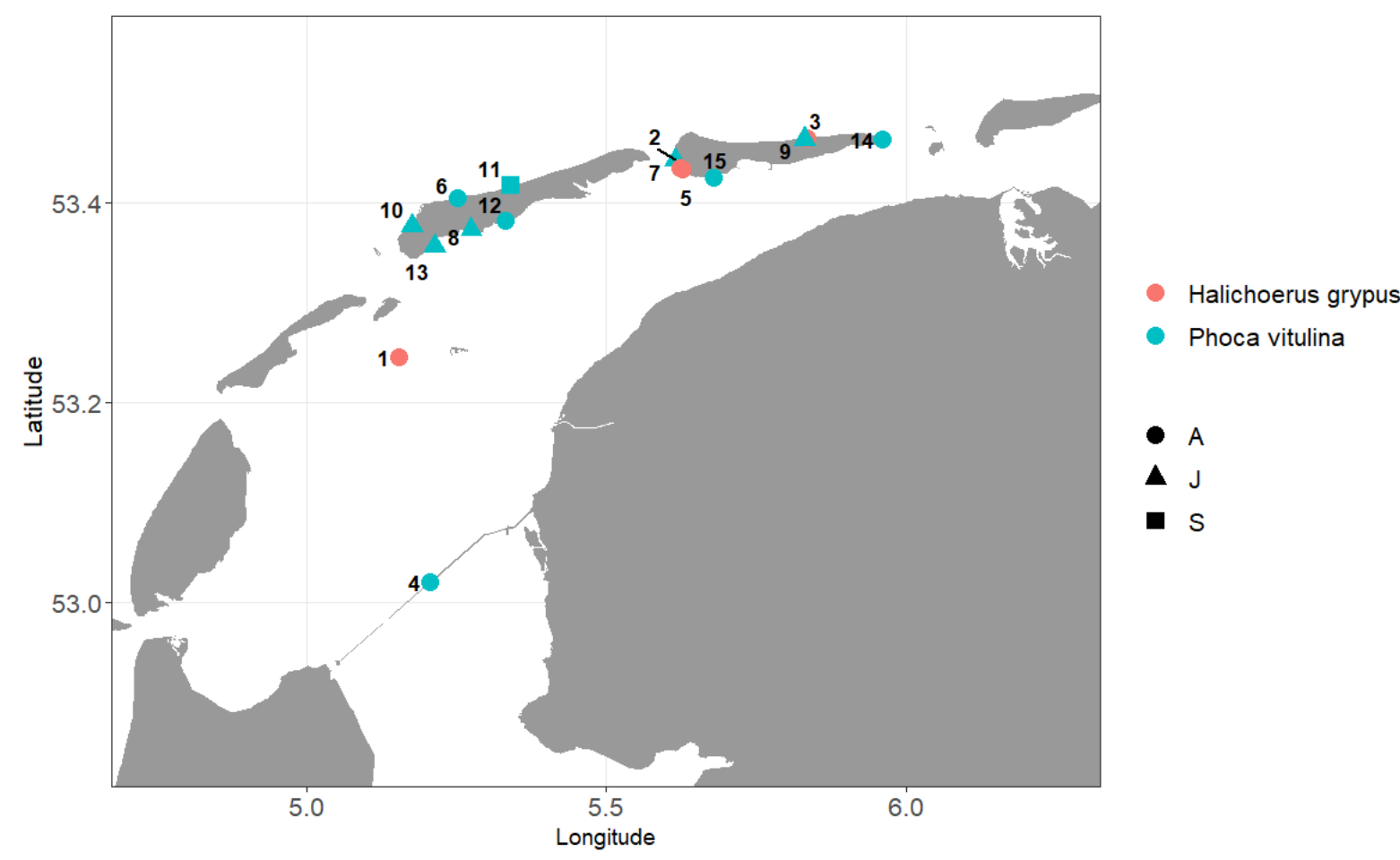

Figuur 2 Locaties van de vijftien gestrande zeehonden in het noorden van Nederland. Grijze zeehonden (Halichoerus grypus) worden weergegeven in het rood en gewone zeehonden (Phoca vitulina) in het licht blauw. De symbolen geven de leeftijdsklassen aan: adult (A), juveniele (J) en sub-adult (S). Details over de zeehonden zijn te vinden in Tabel 2.

De kadavers moesten van goede kwaliteit zijn (geen rotte kadavers) om een zo volledig mogelijke autopsie te kunnen uitvoeren. Dit beperkte de monstername enigszins en vereiste een nauwe samenwerking met de verschillende mensen die terplekke de stranden patrouilleerden.

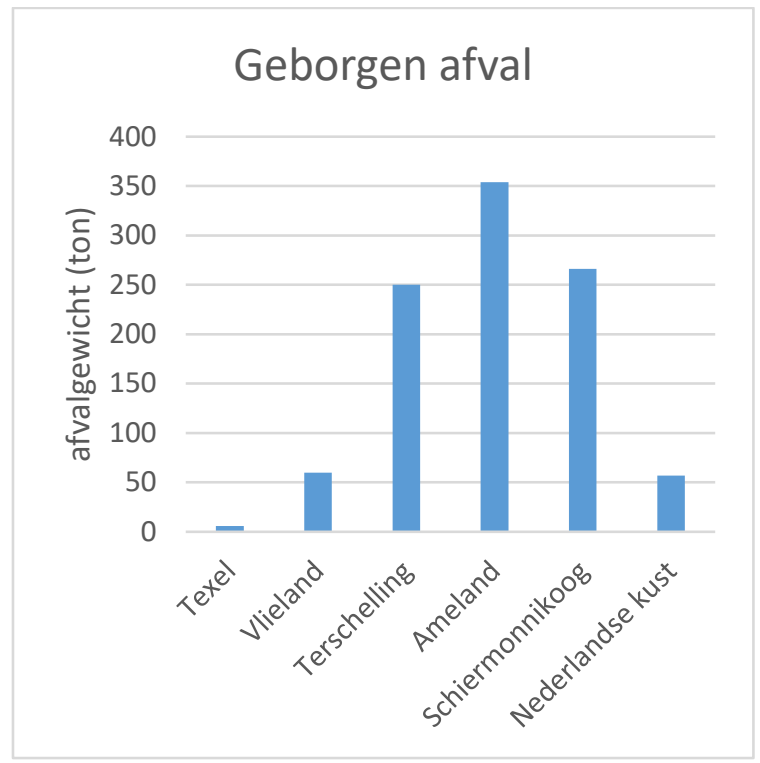

Figuur 3 Hoeveelheid geborgen afval in gewicht langs de Waddeneilanden en de rest van de Nederlandse kust (ER rapportage $\mathrm{t} / \mathrm{m}$ 14 april 2019 MSC ZOE UPDATE 9). Het meeste afval is geruimd op de Waddeneilanden Terschelling, Ameland en Schiermonnikoog.

In totaal zijn zes zeehonden verzameld op Terschelling, zeven op Ameland, één bij de Afsluitdijk (Breezanddijk) en één zeehond direct uit de Waddenzee (Tabel 2). 
Tabel 2 Vijftien zeehonden, waarvan 11 gewone zeehonden ( $P v=$ Phoca vitulina) en 4 grijze zeehonden ( $\mathrm{Hg}=$ Halichoerus grypus) zijn verzameld om de impact door MSC ZOE containers te onderzoeken. De zeehond met nummer 6 was een zwanger vrouwtje, waarvan de foetus (6.1) ook pathologisch is onderzocht. Foto's van de gestrande zeehonden zijn te vinden in Bijlage 1. Meer details per individu zijn te vinden in het pathologie rapport (IJsseldijk and Van den Brand 2020).

\begin{tabular}{|c|c|c|c|c|c|}
\hline Nummer & Datum & Soort & $\begin{array}{l}\text { Leeftijd en } \\
\text { geslacht }\end{array}$ & $\begin{array}{c}\text { Totale } \\
\text { lengte }(\mathrm{cm})\end{array}$ & Locatie \\
\hline 1 & 19 september 2019 & $\mathrm{Hg}$ & Adult $\hat{\jmath}$ & 155 & Waddenzee \\
\hline 2 & 20 januari 2019 & $P V$ & Juveniel $\uparrow$ & 105 & Ameland \\
\hline 3 & 10 februari 2019 & $\mathrm{Hg}$ & Adult $\hat{\sigma}$ & 237 & Ameland \\
\hline 4 & 9 januari 2019 & $P V$ & Adult $q$ & 165 & Breezanddijk \\
\hline 5 & 1 mei 2019 & $H g$ & Adult $\lesssim$ & 229 & Ameland \\
\hline 6 & 28 mei 2019 & $P V$ & Adult $?$ & 168 & Terschelling \\
\hline 6.1 & 28 mei 2019 & $P V$ & Foetus $q$ & 89 & Terschelling \\
\hline 7 & 25 september 2019 & $\mathrm{Hg}$ & Adult $\hat{\sigma}$ & 166 & Ameland \\
\hline 8 & 19 augustus 2019 & $P V$ & Juveniel $\hat{\jmath}$ & 98 & Terschelling \\
\hline 9 & 30 september 2019 & $P V$ & Juveniel $q$ & 99 & Ameland \\
\hline 10 & 13 oktober 2019 & $P V$ & Juveniel $\lesssim$ & 112 & Terschelling \\
\hline 11 & 16 oktober 2019 & $P V$ & Sub-adult $q$ & $110 *$ & Terschelling \\
\hline 12 & 20 oktober 2019 & $P V$ & Adult + & $152 *$ & Terschelling \\
\hline 13 & 15 november 2019 & $P V$ & Juveniel $\lesssim$ & 105 & Terschelling \\
\hline 14 & 22 november 2019 & $P V$ & Adult $\hat{\sigma}$ & 166.5 & Ameland \\
\hline 15 & 1 december 2019 & $P V$ & Adult $\lesssim$ & 156.5 & Ameland \\
\hline
\end{tabular}

* geschatte lengte

\subsection{Pathologisch onderzoek}

De verzamelde zeehonden werden vers getransporteerd en direct op het Veterinair Pathologisch Diagnostisch Centrum (UU) in Utrecht onderzocht. Er werd hiervoor een vast protocol gehanteerd (IJsseldijk en Brand 2020). Hierbij werd na uitvoerig extern en intern onderzoek van elk dier het maag-darmkanaal in een plastic zak ingevroren $\left(-20^{\circ} \mathrm{C}\right)$ voor verdere analyse. 


\subsection{Analyse van maag- en darminhoud}

De verwerking bestond uit het verzamelen van monsters voor eDNA, en om vaste deeltjes, waaronder voedselresten en mogelijk plastics uit de maag/darminhoud te filteren. Elk nieuw monster werd met nieuw gesteriliseerde materiaal verwerkt zodat er geen contaminatie tussen de monsters kon optreden. De magen en darmen werden een dag voordat het verwerkt werd ontdooid in de koelkast.

De ontdooide magen werden verwijderd uit de plastic zak, gewogen en met een scalpel opengesneden. Om een eDNA monster te verzamelen werd er met een lepel maagsap vanuit alle locaties binnenin de maag afgenomen. Het maagsap werd in een pot met Milli-Q gemixt om aanwezig DNA te fixeren. De mix werd verdeeld over twee monsterpotjes en grotere delen in het eerste potje (bijvoorbeeld dieetresten of plastic deeltjes) werden terug gedaan bij de maaginhoud. In het tweede monsterpotje werd 1 op 1 PBS (Phosphate Buffered Saline) toegevoegd (gemaakt volgens het volgende recept: https://www.protocolsonline.com/recipes/phosphate-buffered-salinepbs/\#section-2). Beide monsterpotjes werden ingevroren.

Om eDNA monsters te verzamelen vanuit de darmen werd, met behulp van een injectiespuit, Milli-Q door de darmen gespoeld. Na het spoelen van de volledige darmen, werd het uitgespoelde vocht gemixt en werden hieruit drie lepels in een potje met Milli-Q gemixt. Deze mix werd verdeeld over twee monsterpotjes waarbij grotere delen, bijvoorbeeld dieetresten of plastics deeltjes, werden terug gedaan bij de darmen. In het tweede monsterpotje werd 1 op 1 PBS toegevoegd en beide monsters werden ingevroren.

$\mathrm{Na}$ de DNA-bemonstering werden de magen en darmen uitgespoeld met kraanwater. Na het spoelen werden de lege magen en darmen opnieuw gewogen om de massa van de inhoud te kunnen bepalen. Al het materiaal dat uit de magen en darmen werd gespoeld werd apart verzameld in dubbele waszakken waarbij de binnenste zak een maaswijdte van $300 \mu \mathrm{m}$ had en de buitenste $120 \mu \mathrm{m}$. Voor verdere analyse werden deze restanten in de zakken gewassen zodat het merendeel van het opgelost organisch materiaal werd weggespoeld. Hiertoe werden de dichtgeknoopte zakken in een wasmachine op hoge temperatuur gewassen, inclusief een voorwas met biologische wasmiddel (Bravo Rebolledo et al. 2013; Aarts et al. 2019). Na het wassen werden de monsters aan de lucht gedroogd, en werd het overgebleven materiaal onder de microscoop onderzocht.

\subsubsection{Plastic analyse}

De gewassen monsters werden onderzocht op aanwezigheid van plastics door getrainde lab-analisten werkend volgens een eerder beschreven methode (Van Franeker et al. 2018). Gevonden plastic werd onderverdeeld in 2 categorieën: primair en secondair (Kühn et al. 2020). De primaire plastics zijn de vaak meer solide deeltjes die, naar alle waarschijnlijkheid, in het verteringsstelsel van de zeehond aanwezig waren doordat de zeehond het heeft gegeten of dat het in de gegeten vis zat (Kühn et al. 2020). Secondaire plastics, alle kleine stofachtige vezels, kunnen in het monster zijn terechtgekomen door de verwerking van het monster of doordat het in de maag of darm terecht is gekomen nadat de zeehond is overleden (Kühn et al. 2020). Bij secondair plastic gaat het vaak om vezels die klaarblijkelijk afkomstig zijn uit het materiaal gebruikt in het onderzoek, zoals de zeef of van kleding van de onderzoekers.

Van alle gevonden plastics, dus beide categorieën, zijn de plastic soorten beschreven. Hieronder bijvoorbeeld pellets (de grote industriële en ook de micro-beads), vellen, draden (touw en vezels), (piep-)schuim en fragmenten. De primaire plastics die in het verteringstelsel werden aangetroffen, werden vergeleken met de verloren lading van de MSC ZOE. Hiertoe is gebruik gemaakt van een openbare lijst: https://www.rijksoverheid.nl/documenten/wob-verZOEken/2019/05/09/besluit-wobverZOEk-lading-msc-ZOE. 


\subsubsection{Dieet analyse}

Door de tijdelijke sluiting van de laboratoria (i.v.m. CORONA) was het niet mogelijk de verzamelde DNA-monsters te analyseren en zo de vissoorten te identificeren die in het verteringstelsel van de zeehonden aanwezig waren.

Wel werd in elk gewassen monster onder de microscoop gezocht naar prooiresten (veelal visbotten) waaruit het dieet van de zeehond ook kan worden bepaald. Aan de hand van gidsen en eigen collecties is het mogelijk uit de vorm van onder andere otolieten, maar ook bijvoorbeeld wervels, kieuwdeksels en kaken de prooisoorten te identificeren (Camphuysen and Henderson 2017; Härkönen 1986; Watt, Pierce, and Boyle. 1997). 


\section{Resultaten}

\subsection{Strandingen van dode zeezoogdieren 2013-2019}

In het noorden van Nederland (in het onderzoeksgebied tussen 4.5-7.5 oosterlengte en 52.8-53.7 noorderbreedte) zijn er tussen 2013 en 2019 in totaal 1484 dode gewone zeehonden en 245 dode grijze zeehonden gemeld op waarneming.nl door Ecomare, EHBZ en RTZ.

Het aantal gemelde dode gewone zeehonden laat een toenemende trend zien tussen 2013 en 2019 (Figuur 4a). Hierbij neemt het aantal toe van 108 dode dieren in 2013 tot 331 exemplaren in 2019, dit zijn vooral juveniele zeehonden. In 2013 en 2014 zijn naar verhouding veel individuen gemeld zonder leeftijdsklasse.

Per locatie is er veel variatie in het aantal dood gestrande gewone zeehonden tussen de jaren 2013 en 2019 (Figuur 5a). Zo verdubbelt bijvoorbeeld het aantal meldingen op Vlieland tussen 2013 en 2019 en neemt het aantal het jaar daarna weer af. In 2019 is op Terschelling het aantal strandingen van dode gewone zeehonden toegenomen tot 56 gewone zeehonden. Dit is meer dan verdubbeld ten opzichte van het hoogste aantal strandingen tussen 2013 en 2018 van 22 gewone (Figuur 5a). Ook namen de aantallen in 2019 toe op Ameland en langs het vasteland, terwijl op de andere locaties geen bijzonderheden waar te nemen zijn.

In 2019, na de MSC ZOE ramp is een toename van het aantal dood gestrande gewone zeehonden waargenomen ten opzichte van voorgaande jaren (Figuur 4). Zowel van adulte gewone zeehonden ( $51 \% ;+32$ dieren) als jongere gewone zeehonden $(63 \% ;+83$ dieren). Toch is het onduidelijk of er sprake is van een trendbreuk: het aantal gemelde strandingen (vooral bij jonge dieren) varieert bij deze soort sterk.

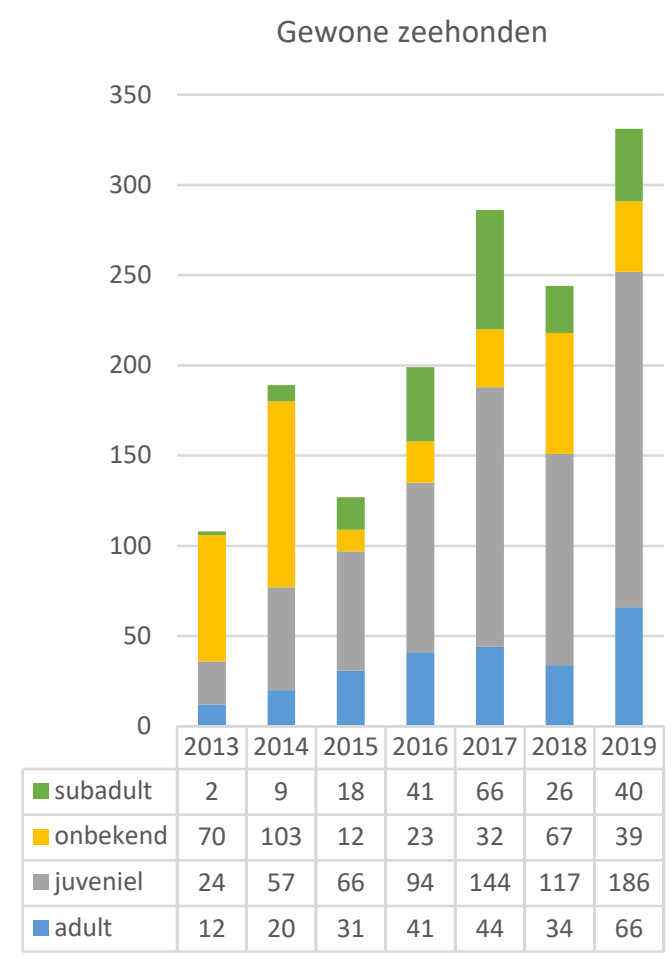

A
Grijze zeehonden

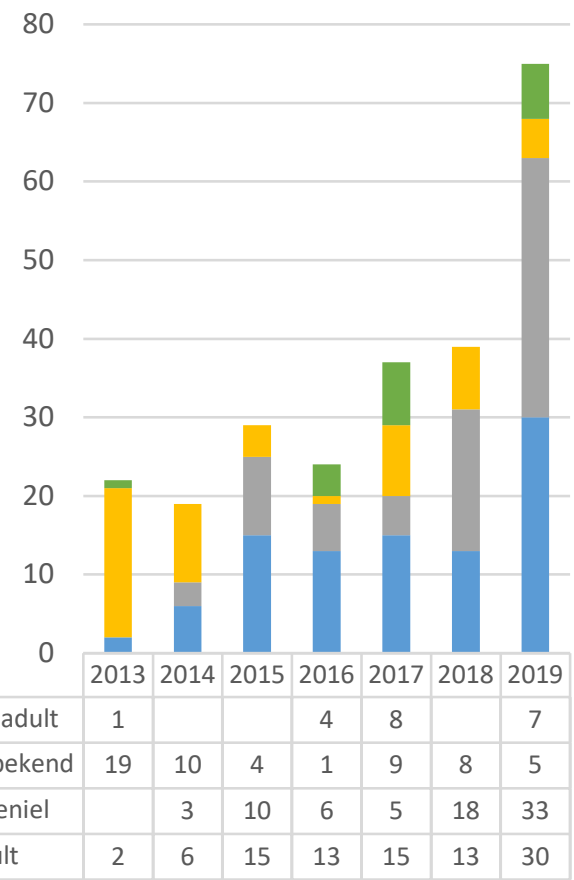

B

Figuur 4 Strandingen van dode gewone (a) en grijze zeehonden (b) vanaf 2013 tot en met 2019 in het Waddengebied (4.5-7.5 Oosterlengte en 52.8-53.7 Noorderbreedte), waarbij onderscheid gemaakt is per leeftijdscategorie. Indien 'onbekend' is er geen leeftijdscategorie aangegeven bij de 
melding. Deze getallen komen van vrijwillige invoer op Waarneming.nl door Ecomare Texel, RTZ (Archief J. v.d. Hiele) en Zeehondencentrum Pieterburen.

In vergelijking met gewone zeehonden zijn beduidend minder strandingen van dode grijze zeehonden gemeld. In het onderzoeksgebied is tussen 2013 en 2019 een toenemende trend van het aantal gemelde dode grijze zeehonden waar te nemen (Figuur 4b). Het aantal liep op van 22 dode grijze zeehonden in 2013 tot 75 in 2019. Er is geen duidelijk verschil in de verhouding tussen de verschillende leeftijdscategorieën, daarbij in acht nemend dat er in de jaren 2013 en 2014 een hoog aantal onbekende leeftijdscategorieën waren.

Vanaf 2013 zijn in alle jaren de meeste dode grijze zeehonden gevonden op Vlieland (Figuur 5b), waar jaarlijks tussen de 11 en 28 dode grijze zeehonden zijn aangetroffen.

Het aantal gestrande dode grijze zeehonden is in 2019 op alle locaties toegenomen, behalve op Schiermonnikoog en Texel. Op Vlieland steeg het aantal strandingen met 200\% tussen 2013 en 2018 (+11 zeehonden), in 2019 nam dit nog eens met 127\% toe. Het aantal dode grijze zeehonden op Terschelling nam toe van 2 dieren in 2013 tot 3 dieren in 2018, terwijl er in 201918 zeehonden zijn gemeld. Het aantal op Ameland nam toe van 1 melding in 2013 tot 4 meldingen in 2018, in 2019 waren dit 10 grijze zeehonden. Langs het vaste land in het noorden van Nederland nam het aantal van 2 dieren toe tot 6 dieren tussen 2013 en 2018, het aantal in 2019 was 14 dode grijze zeehonden. In het geheel namen de aantallen grijze zeehonden in 2019 met $41 \%$ (36 dieren) toe.

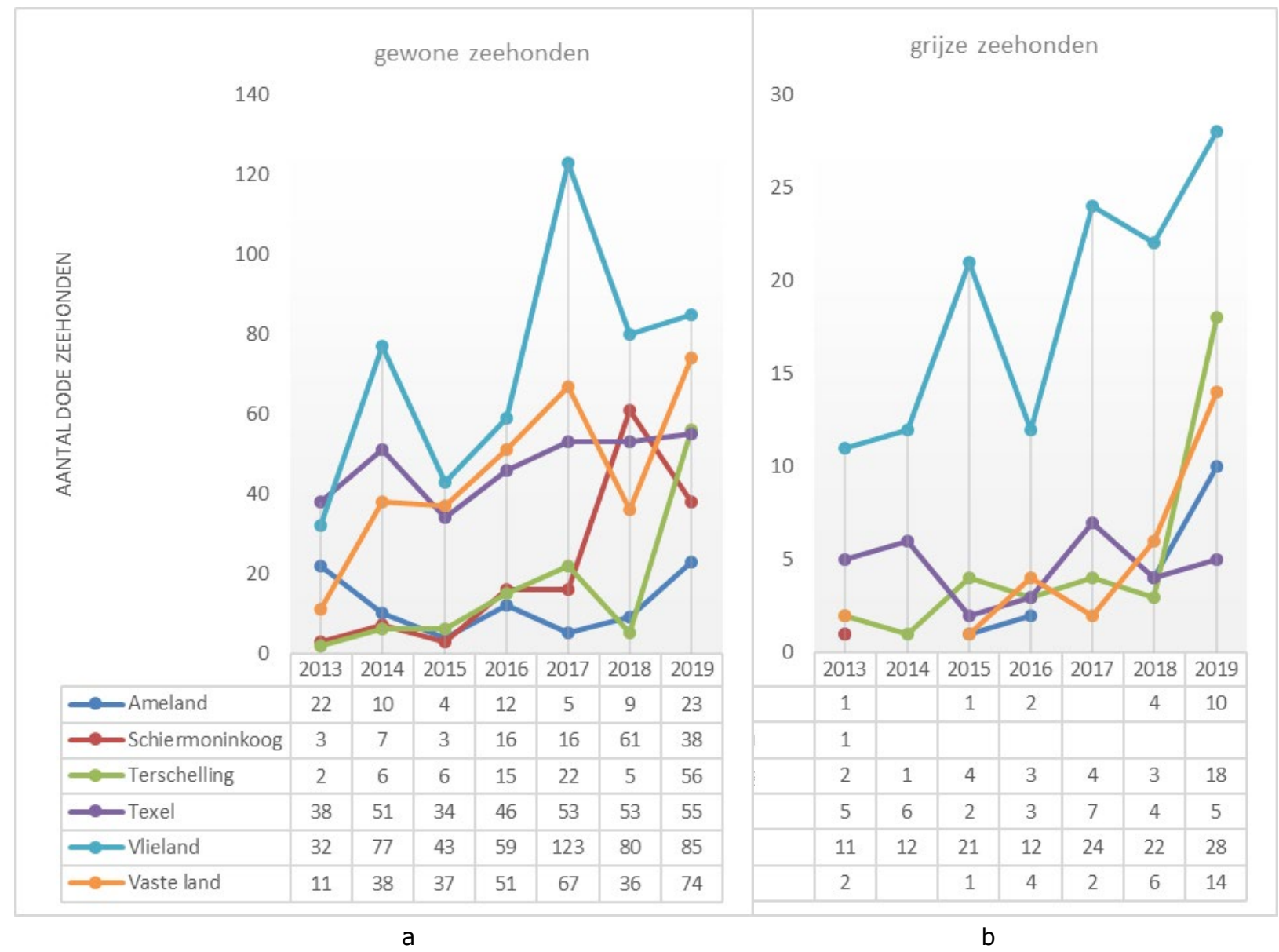

Figuur 5 Strandingen van dode gewone (a) en grijze zeehonden (b) vanaf 2013 tot en met 2019, waarbij onderscheid gemaakt is tussen verschillende locaties in het Waddengebied (4.5-7.5 Oosterlengte en 52.8-53.7 Noorderbreedte).

\subsection{Doodsoorzaken van vijftien gestrande zeehonden}

Tussen 9 januari en 1 december 2019 zijn vijftien dode zeehonden verzameld (Tabel 2). IJsseldijk en Brand (2020) beschreven hiervan de pathologische bevindingen en de meest waarschijnlijke 
doodsoorzaak (samengevat in Tabel 3). Eén van de grijze zeehonden (nr. 7) is hoogstwaarschijnlijk omgekomen door beknelling onder water: er werd een lineaire afdruk met zwellingen en bloedingen in het onderliggende weefsel gevonden. Bij een gewone zeehond ( $\mathrm{nr} .11$ ) was dit minder duidelijk, het dier stierf mogelijk door stomp trauma of als bijvangst. Bij geen van de vijftien zeehonden werd plastic aangetroffen dat verwikkeld was om een lichaam. Een van de gewone zeehonden bleek in een vis gestikt te zijn. Verder werden zeven andere dieren (vooral gewone zeehonden) aangetroffen die stierven als gevolg van falen van de ademhaling; de meeste hiervan door ontstekingen van de longen of door parasieten. Daarnaast stierven twee dieren aan darmproblemen, en van drie overige dieren kon geen duidelijke doodsoorzaak gevonden worden.

\begin{tabular}{|c|c|c|c|c|}
\hline Soort & $\begin{array}{l}\text { Aantal } \\
\text { individuen }\end{array}$ & $\begin{array}{l}\text { Waarschijnlijke } \\
\text { Doodsoorzaak }\end{array}$ & Bijzonderheden & ID \\
\hline \multirow{4}{*}{$\begin{array}{l}\text { Grijze zeehond } \\
\text { Halichoerus grypus }\end{array}$} & 1 & ademhaling falen & beknelling & 7 \\
\hline & 1 & ademhaling falen & gezwel in longen & 5 \\
\hline & 1 & buikvliesontsteking & darmperforatie & 3 \\
\hline & 1 & onbekend & chronisch & 1 \\
\hline \multirow{6}{*}{$\begin{array}{l}\text { Gewone zeehond } \\
\text { Phoca vitulina }\end{array}$} & 5 & ademhaling falen & longontsteking/-parasieten & $\begin{array}{l}2,8,9 \\
10,13\end{array}$ \\
\hline & 1 & ademhaling falen & longparasieten, geëuthanaseerd & 15 \\
\hline & 1 & ademhaling falen & $\begin{array}{l}\text { verstikking in voedsel, was } \\
\text { zwanger }\end{array}$ & 6 \\
\hline & 1 & trauma of bijvangst & & 11 \\
\hline & 1 & darmtorsie & & 14 \\
\hline & 2 & onbekend & ontsteking- acuut/chronisch & 4,12 \\
\hline
\end{tabular}

\subsection{Maag- en darminhoud}

\subsubsection{Plastics}

De maag- en darminhoud van de vijftien gestrande zeehonden is onderzocht op aanwezigheid van plastics. Van alle onderzochte dieren had één zeehond een voorwerp dat als primair plastic werd geclassificeerd in het spijsverteringsstelsel: in de darmen van zeehond nummer 8 is plantaardig materiaal gevonden. Het betrof een zaaddoosje. Het is onduidelijk of dit materiaal gegeten is. In het spijsverteringstelsel van alle vijftien zeehonden zijn objecten die als secundair plastic werden geclassificeerd gevonden. Deze bestonden uit vezels van de zeef en kleding die onderzoekers droegen tijdens de verwerking, touwtjes waarmee de maag en darmen dichtgeknoopt zaten en onderdelen welke afkomstig waren van de monsterpotjes of gebruikt zijn tijdens het zeven.

Van twee niet solide plastic objecten, gecategoriseerd als secundair, kon de herkomst niet worden herleid. In de darm van zeehond nummer 16 werden witte langwerpige schilfers/fragmenten gevonden, waarvan een zijde plat en andere zijde licht gerond (0,5-2 mm lang en 0,5 mm breed). Als tweede werd in de maag van zeehond nummer 7 een doorzichtig, broos plastic vel van een aantal millimeters gevonden.

Geen van de objecten in de verteringskanalen van de zeehonden kon in relatie gebracht worden met de verloren lading van de MSC ZOE.

Daarnaast werd in de maag of darm van 12 dieren zand gevonden; in 10 dieren zeehonden haren.

\subsubsection{Dieet}

Als gevolg van de beperkingen ter bescherming tegen het CORONA virus, was het niet mogelijk de dieetresten in detail te bekijken en te meten. Hierdoor kan enkel een eerste indicatie worden gepresenteerd van het dieet van de zeehonden. Bij een eerste analyse van de resten werden er vooral 
bodemvissen, met name platvissen gevonden. Het grootste aantal visresten werd aangetroffen in zeehond nummer 6, waarbij in totaal minimaal 1031 prooienresten zijn gevonden. Hiervan konden vijf verschillende soorten worden onderscheiden (Tabel 4). Acht verschillende prooisoorten zijn onderscheiden uit de maag van zeehond nummer 1 , waarin in totaal 35 resten zijn gevonden. In de maag van zeehond nummer 2 zijn zeven verschillende vissoorten onderscheiden, waarvan in totaal 26 visresten zijn gevonden.

Tabel 4. Voorlopige lijst van visresten in spijsverteringstelsel. Maag ( $m$ ) en darm (d) van de onderzochte zeehonden, met een indicatie voor het minimum aantal vissen. * = (nog) niet nader gespecificeerd. Gewone zeehonden zijn in het zwart weergegeven, grijze zeehonden in het blauw. i.v.m. Corona is het volledig detailonderzoek niet uitgevoerd.

\begin{tabular}{|c|c|c|c|c|c|c|c|c|c|c|c|c|c|c|c|}
\hline \multirow[b]{2}{*}{ 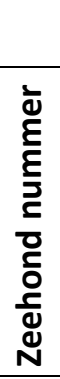 } & \multirow[b]{2}{*}{ 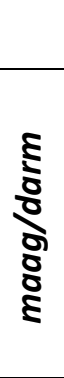 } & \multicolumn{13}{|c|}{ Minimum aantal individuele vissen } & \multirow[b]{2}{*}{ 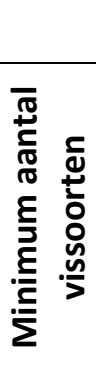 } \\
\hline & & 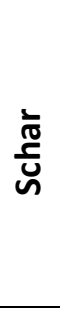 & 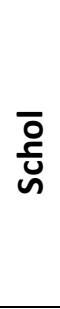 & 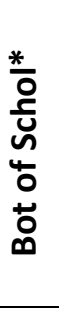 & 范 & 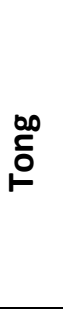 & 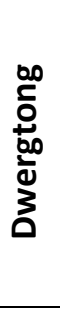 & $\frac{\stackrel{*}{*} \frac{n}{\sum^{\frac{n}{2}}}}{\frac{\pi}{a}}$ & $\frac{n}{2}$ & $\begin{array}{l}\overline{\mathbf{g}} \\
\overline{0} \\
\overline{0} \\
\bar{v}\end{array}$ & $\begin{array}{l}\frac{00}{\frac{0}{5}} \\
. \frac{0}{0} \\
\frac{0}{0} \\
\frac{0}{N} \\
\text { N }\end{array}$ & 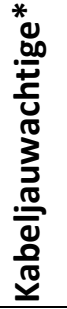 & 点 & $\stackrel{*}{\frac{n}{5}}$ & \\
\hline \multirow{2}{*}{1} & $m$ & 5 & & 5 & & 1 & 1 & 1 & 1 & 20 & & & & 1 & 8 \\
\hline & d & & & & & & & & & & & & & & 0 \\
\hline \multirow{2}{*}{2} & $m$ & 5 & & 5 & & 5 & 10 & & & 1 & & & 5 & 1 & 7 \\
\hline & d & & & & & & & 1 & & & & & & & 1 \\
\hline \multirow{2}{*}{3} & $m$ & & & & & & & & & 5 & & & & 1 & 2 \\
\hline & $d$ & & & & & & & & & & & & & 2 & 1 \\
\hline \multirow{2}{*}{4} & $m$ & & & & & 1 & & & & 21 & & & & 1 & 3 \\
\hline & d & & & & & & & & & & & & & 2 & 1 \\
\hline \multirow{2}{*}{5} & $m$ & & & & & & & & & & & & & & 0 \\
\hline & d & & & & & & & & & & & & & 1 & 1 \\
\hline \multirow{2}{*}{6} & $m$ & 10 & & 10 & & & & & 10 & 1000 & & & & 1 & 5 \\
\hline & d & 10 & & 10 & & 20 & & & 1 & & 5 & & & & 5 \\
\hline \multirow{2}{*}{7} & $m$ & & & & 1 & & & 1 & & 2 & 1 & & & 1 & 5 \\
\hline & d & & & & & & & 1 & & & & & & 1 & 2 \\
\hline \multirow{2}{*}{8} & $m$ & & & & & & & & & & & & & 2 & 1 \\
\hline & $d$ & 1 & & & & 1 & & & & & & & & & 2 \\
\hline \multirow{2}{*}{9} & $m$ & & & & & & & & & & & & & 1 & 1 \\
\hline & $d$ & & & & & & & & & & & & & 1 & 1 \\
\hline \multirow{2}{*}{10} & $m$ & & & & & 1 & & & & & & & & 1 & 2 \\
\hline & $d$ & & & & & & & & & & & & & & 0 \\
\hline \multirow{2}{*}{11} & $m$ & & & & & & & & & & & & & 1 & 1 \\
\hline & $d$ & & & & & & & 1 & & & & & & 1 & 2 \\
\hline \multirow{2}{*}{12} & $m$ & & & & & & & & & & & & & 1 & 1 \\
\hline & $d$ & & & & & & & 1 & & & & & & 1 & 2 \\
\hline \multirow{2}{*}{13} & $m$ & & & & & 1 & & & & & & & & 1 & 2 \\
\hline & $d$ & & & & & & & & & & & & & 1 & 1 \\
\hline \multirow{2}{*}{14} & $m$ & 1 & & & & 1 & & 1 & & & & & & 1 & 4 \\
\hline & $d$ & & & 1 & & & 1 & & & & & 1 & & 1 & 4 \\
\hline \multirow{2}{*}{15} & $m$ & & & & & & & & & & & & & 2 & 1 \\
\hline & $d$ & & & & & & & & & & & & & & 0 \\
\hline
\end{tabular}




\section{Discussie}

\subsection{Strandingen}

De geselecteerde registraties in Waarneming.nl tussen 2013 tot 2019 laten een toename in het aantal strandingen van dode gewone zeehonden in het studiegebied zien. Er zijn wel relatief veel schommelingen in de aantallen tussen 2013 en 2019, waardoor het niet duidelijk is of de waargenomen toename in aantal dood gevonden gewone zeehonden in 2019 een voortzetting is van een toenemende trend in dood gevonden dieren. Doordat er veel variatie waargenomen is tussen de voorgaande jaren, is niet te zeggen of de toename in het aantal dode gewone zeehonden komt door de verloren lading van de MSC ZOE. Opvallend is wel de toename in aantal gevonden adulte dieren. Het aantal strandingen van dode grijze zeehonden neemt duidelijk toe in 2019, het jaar nadat de MSC ZOE een deel van zijn lading verloor. Voor beide soorten kan niet geconcludeerd worden of deze toename te maken heeft met de verloren lading van de MSC ZOE. Het nodigt echter wel uit, voor beide soorten, tot nader onderzoek naar een mogelijke relatie.

Het aantal gevonden dode zeehonden is slechts een deel van de totale hoeveelheid dode zeehonden. Een deel van de dode dieren zal mogelijk afzinken naar de bodem van de zee en niet aanspoelen langs de kust, of door de stroming verder worden getransporteerd. De hoeveelheid gevonden dode zeezoogdieren dat langs de kust strandt kan beïnvloed worden door o.a. de tijd van het jaar, de getijdewerking en bijvoorbeeld de windrichting (Brasseur 2018; Johnston et al. 2015; Soulen et al. 2013; Peltier et al. 2013), maar ook door de inzet waarmee naar de dieren wordt gezocht. In Nederland worden de meeste kustlijnen veelvuldig bezocht, hoewel zeehonden ook zouden kunnen stranden op kwelders en andere voor het publiek gesloten gebieden.

Daarnaast moet de verandering in populatiepopulatie grootte in acht genomen worden, omdat het aannemelijk is dat bij een grotere populatie meer dode dieren zullen stranden (Brasseur 2018). Veranderingen in de populatiegrootte worden jaarlijks gemonitord door het uitvoeren van tellingen (Cremer et al. 2017). Beide soorten zeehonden worden op twee momenten in het jaar geteld: tijdens de rui worden alle zeehonden geteld en tijdens de pup periode worden de pups geteld. In de internationale Waddenzee groeit het aantal pups van de gewone zeehond jaarlijks terwijl er al sinds 2013 geen groei wordt waargenomen in de totale aantallen (Galatius et al. 2018). Het is onduidelijk of er onder de gewone zeehonden een hoge sterfte plaatsvindt dat het aantal geboren pups evenaart, of dat er een fundamentele gedragsverandering is opgetreden. Duidelijk is wel dat in de internationale Waddenzee het aantal gewone zeehonden een trendbreuk laat zien in vergelijking met eerdere jaren waarbij de populatie herstellende was van met name zware overbejaging (en virussterfte). De aantallen getelde grijze zeehonden tijdens de pup periode en de rui periode nemen vooralsnog elk jaar toe in de Internationale Waddenzee (Cremer et al. 2019). Met een grotere grijze zeehondenpopulatie is ook het aantal dood gestrande grijze zeehonden groter.

Om eventuele afwijkingen in het aantal strandingen van gewone of grijze zeehonden te kunnen opmerken is een goed strandingsregistratiesysteem noodzakelijk. Dit zou een goed beeld kunnen geven van het aantal dode dieren, maar ook van de verspreiding van de vondsten, doodsoorzaken en eventuele specifieke groepen (onder andere jong/oud). Daarnaast vormt een goede strandingsregistratie en bemonstering voor autopsie een basis voor een beter begrip van de veranderingen in populatie parameters, zoals fecunditeit, leeftijdsopbouw, en individuele groei en gezondheid.

\subsection{Pathologisch onderzoek}

In het pathologisch protocol is een inspectie van de maag en darm opgenomen, waarbij een potentieel probleem ontstaat: bij het openmaken van deze organen kan er ongewild een deel van de maag- of 
darminhoud uit het orgaan komen, of kunnen vreemde stoffen erin komen. Bij 10 van de 15 zeehonden werden zeehondenharen in de maag/darm gevonden. Dit wijst erop dat tijdens het onderzoek bij het merendeel van de dieren vervuiling in de maag is gekomen. Het is de eerste keer dat dit soort pathologisch onderzoek is gedaan met zeehonden, en in toekomstig onderzoek kunnen andere protocollen aangehouden worden om vervuiling van de monsters of verlies van maag en darminhoud te minimaliseren.

Geen van de vijftien zeehonden werd aangetroffen met plastic of ander afval dat om het lichaam heen verwikkeld was. Wel zijn twee zeehonden mogelijk acuut overleden en een niet natuurlijke dood gestorven. Eén grijze zeehond is waarschijnlijk omgekomen door beknelling onderwater. Bij een andere, gewone, zeehond, zijn er sporen gevonden van een mogelijke beknelling of een stomp trauma, maar de doodsoorzaak van dit dier was minder duidelijk doordat het kadaver in een verdere staat van ontbinding was. Voor deze twee zeehonden kan dit duiden op een doodsoorzaak door een niet natuurlijk voorwerp (dit had ook bijvoorbeeld bijvangst kunnen zijn) in het water. Eén dier stierf aan de gevolgen van een perforatie van zijn darm wat een gevolg zou kunnen zijn van een scherp voorwerp in het verteringsstelsel, helaas is een dergelijk voorwerp niet gevonden. Bij alle andere onderzochte zeehonden leken er geen directe doodsoorzaken te zijn die gelinkt kan worden met antropogene oorzaken, laat staan met MSC ZOE. Gezien de kleine steekproef is het echter niet uit te sluiten dat er een (in)direct verband zou kunnen zijn. Hierbij speelt een belangrijke rol dat nog niet veel bekend is over doodsoorzaken van zeehonden in Nederland, maar ook in de internationale literatuur ontbreekt het aan onderzoeken naar normale doodsoorzaken bij zeehonden. Een recent overzicht van strandingsonderzoeken van zeezoogdieren (ICES 2020, in voorbereiding) laat zien dat er weinig gebieden zijn waar structureel gekeken wordt naar strandingen van zeehonden, nog minder waar onderzoek wordt verricht en gepubliceerd over de doodsoorzaken. Een structureel onderzoek naar doodsoorzaken van zeehonden zou fundamentele kennis opleveren, waarbij effect studies meer solide worden kunnen worden.

Wageningen Marine Research heeft in het verleden vrijwillig en op eigen initiatief, in samenwerking met Universiteit Utrecht en Ecomare, dode zeehonden bijeengebracht. Deze dood gestrande zeehonden werden tussen 2009 en 2015 rondom Texel verzameld en werden door studenten van de opleiding diergeneeskunde aan de Universiteit Utrecht bekeken. Door gebrek aan fondsen zijn de verzamelde gegevens nooit goed geanalyseerd en zijn de maag- en darminhoud niet onderzocht. Uit een eerste overzicht blijkt $\sim 13 \%$ van deze zeehonden een inwendig of uitwendig letsel te hebben gehad, waarvan waarschijnlijk 5\% geclassificeerd werd als mogelijke bijvangst en bij 8\% zou een letsel fataal zijn geweest. Verder was de doodsoorzaak niet duidelijk bij $50 \%$ van de zeehonden, en overleed $\sim 36 \%$ waarschijnlijk aan parasieten en infecties. Voor zover beschikbaar zullen de magen en darmen van deze dieren in het kader van het vervolgonderzoek naar effecten van MSC ZOE van Rijkswaterstaat worden onderzocht.

Het is niet te bewijzen of uit te sluiten dat de vijftien verzamelde zeehonden overleden zijn door de verloren containers van de MSC ZOE. Er zijn geen directe bewijzen gevonden. De analyses van de 15 dieren in dit project kunnen gezien worden als een vertrekpunt voor een structurele analyse van mogelijke doodsoorzaken bij zeehonden.

Het is raadzaam een structurele registratie en onderzoek van dood gestrande zeehonden op te zetten. Het niet geborgen materiaal van de MSC ZOE containers zal langdurig in het milieu blijven. Gezien de lange levensduur van zeehonden is het mogelijk dat mettertijd dieren gevolgen zullen ondervinden van de verloren lading. Ook in het kader van andere menselijke activiteiten is het raadzaam om de beschermde zeehondensoorten op deze wijze te monitoren. Bovendien zal hiermee voldaan worden aan een nieuwe EU-regeling die de lidstaten verplicht stelt wetenschappelijke gegevens te verzamelen met betrekking tot mogelijke bijvangst van alle soorten die vallen onder de habitatrichtlijn (EU) 2019/1241 (zie ook ICES 2020, in voorbereiding).

\subsection{Maag- en darmanalyse}

Als gevolg van de CORONA-maatregelen is het helaas niet mogelijk geweest het DNA-onderzoek uit te voeren, waarbij potentieel prooiresten gevonden kunnen worden waarvan geen botresten in het 
verteringsstelsel waren achtergebleven. De verzamelde monster blijven bewaard en kunnen, indien budget aanwezig, op een later moment verwerkt worden. Daarnaast is het ook niet mogelijk geweest de noodzakelijke uitgebreide analyses van de gevonden prooiresten uit te voeren.

\subsubsection{Aanwezigheid van plastic}

Geen van de 15 zeehondenmagen of darmen (4 grijze en 11 gewone zeehonden) bleek primaire plastics te bevatten. De hoeveelheid gepubliceerde onderzoeken naar plastics in zeehonden is gering, maar hieruit bleek dat ongeveer $2 \%$ van de 1062 onderzochte gewone zeehonden magen/darmen plastics bevatte, en van de (slechts) 126 onderzochte grijze zeehonden $5 \%$ plastics bevatte (Tabel 1 , Kühn and van Franeker 2020).

Gezien de mogelijk lage kans plastics aan te treffen in zeehonden, werd eerder geadviseerd meer dieren te onderzoeken. Zo zouden er ten minste 20-50 dieren moeten worden onderzocht voordat plastics in de maag/darmen verwacht kunnen worden. Daarnaast is, door het ontbreken van referentiemateriaal, (nog) geen informatie is over wat zeehonden normaal gezien aan plastic (of andere antropogene stoffen) in hun verteringstelsel hebben. Alleen met structureel onderzoek is het mogelijk om een effect na een incident, zoals het verliezen van scheepscontainers, efficiënt te kunnen meten.

\subsubsection{Relatie tussen dieet en plastic}

Doordat zeehonden hun prooi veelal in zijn geheel opeten, zijn er twee verschillende paden hoe zeehonden plastics in hun verteringstelsel kunnen krijgen: doordat ze plastics met hun prooi verwarren of opzuigen tijdens het foerageren en dit direct binnen krijgen (Bravo Rebolledo et al. 2013), of door het eten van een prooi dat plastics in zijn maag heeft (Nelms et al. 2018). Het is daarom van belang te achterhalen wat de kans is dat specifieke prooisoorten plastics in hun lichaam heeft. Zeehonden kenmerken zich door een grote individuele variatie, en het is daarom niet ondenkbaar dat het voorkomen van plastics gerelateerd is aan een specifieke prooivoorkeur, aangezien de hoeveelheid plastics per prooisoort kunnen variëren. Zeehonden foerageren vooral op benthische en demersale (bodem gebonden) vissoorten. Dit blijkt ook uit de maaginhoud van de vijftien onderzochte dieren. De gevonden vissoorten voeden zichzelf op hun beurt met kleinere prooisoorten, wat in potentie een vermeerdering van inname van kleine plastic deeltjes kan betekenen (Moore et al. 2001). In de bestudeerde zeehonden in deze studie zijn geen plastics aangetroffen, maar in eerdere studies zijn bij deze vissoorten wel plastics aangetroffen (Tabel 5).

\begin{tabular}{|c|c|c|}
\hline Soort & $\begin{array}{l}\text { Aantal studies met } \\
\text { aanwezigheid van plastics } \\
\text { in het verteringsstelsel }\end{array}$ & Referentie \\
\hline $\begin{array}{l}\text { Schar } \\
\text { (Limanda limanda) }\end{array}$ & $3 / 3$ & $\begin{array}{l}\text { McGoran et al. 2018; Murphy et al. 2017; Rummel } \\
\text { et al. } 2016\end{array}$ \\
\hline $\begin{array}{l}\text { Schol } \\
\text { (Pleuronectes platessa) }\end{array}$ & $3 / 3$ & $\begin{array}{l}\text { McGoran, Clark, and Morritt 2017; Murphy et al. } \\
\text { 2017; Welden, Abylkhani, and Howarth } 2018\end{array}$ \\
\hline $\begin{array}{l}\text { Bot } \\
\text { (Platichthys flesus) }\end{array}$ & $8 / 8$ & $\begin{array}{l}\text { Bessa et al. 2018; Day 1988; Kartar, Milne, and } \\
\text { Sainsbury 1973; Kartar, Abou-Seedo, and } \\
\text { Sainsbury 1976; A.R. McGoran, Clark, and Morritt } \\
\text { 2017; Alexandra R. McGoran et al. 2018; Murphy } \\
\text { et al. 2017; Rummel et al. } 2016\end{array}$ \\
\hline $\begin{array}{l}\text { Tong } \\
\text { (Solea solea) }\end{array}$ & $3 / 3$ & $\begin{array}{l}\text { Pellini et al. 2018; Anastasopoulou et al. 2018; } \\
\text { McGoran et al. } 2018\end{array}$ \\
\hline $\begin{array}{l}\text { Grondel } \\
\text { (Gobius minutus) }\end{array}$ & $2 / 2$ & $\begin{array}{l}\text { Day 1988; Kartar, Abou-Seedo, and Sainsbury } \\
1976\end{array}$ \\
\hline $\begin{array}{l}\text { Zandspiering } \\
\text { (Ammodytes personatus) }\end{array}$ & $1 / 1$ & Hipfner et al. 2018 \\
\hline $\begin{array}{l}\text { Wijting } \\
\text { (Merlangius merlangus) }\end{array}$ & $4 / 4$ & $\begin{array}{l}\text { Foekema et al. 2013; Lusher, McHugh, and } \\
\text { Thompson 2013; McGoran et al. 2018; Steer et al. } \\
2017\end{array}$ \\
\hline
\end{tabular}


Het is echter niet te verwachten dat zeehonden continu een volle maag hebben. Bovendien was een relatief groot deel van de onderzochte dieren ziek waardoor het aannemelijk is dat ze niet normaal of in ieder geval niet optimaal foerageerden. Dit blijkt ook uit de resultaten: maar 3 dieren hadden meer dan alleen sporen van voedsel in hun maag. Hiermee is de kans op het vinden van plastics afkomstig uit het dieet relatief klein.

Om de aanwezigheid op (micro)plastics te monitoren bij levende zeehonden, kan plasticonderzoek ook uitgevoerd worden met uitwerpselen gevonden op hun ligplaatsen (Hudak and Sette 2019). Het voordeel hiervan is dat op deze wijze gezonde zeehonden onderzocht worden. Een keer zijde hiervan is dat bij het verzamelen hiervan een kans bestaat dat dieren verstoord kunnen worden op hun rust plek.

Met vijftien dieren is een eerste beeld verkregen van waarschijnlijke doodsoorzaken van zeehonden. Daarnaast zijn protocollen ontwikkeld voor het verzamelen van zeehonden en het verwerken van de ingewanden. Deze protocollen kunnen mogelijk weer van toepassing kunnen zijn bij het optuigen van een meer structurele onderzoek naar strandingen, tenminste bij het vervolgonderzoek van Rijkswaterstaat waarbij eerder verzamelde magen (2009-2014) onderzocht worden. 


\section{Conclusies en aanbevelingen}

Voor dit project is de vraag "Hebben gewone en grijze zeehonden hinder ondervonden van het incident waarbij de MSC ZOE geladen containers verloor in begin 2019?", met een drietal sub-vragen gedefinieerd. Hieronder zijn per sub-vraag de conclusies beschreven.

1) Is er een toename in het aantal strandingen van zeehonden langs de Noord-Nederlandse kusten?

In beide soorten zeehonden is een toename van het aantal gestrande dieren in 2019 waargenomen. In totaal werden in 2019, 406 zeehonden dood aangetroffen langs de Waddenstranden: 331 gewone zeehonden en 75 grijze zeehonden. Deze toename is bij de grijze zeehonden relatief hoger. Met alleen de data uit Waarneming. $\mathrm{nl}$ is het niet mogelijk conclusies te trekken over een mogelijke relatie met het container verlies van MSC ZOE.

2) Waar zijn de zeehonden aan doodgegaan?

De vijftien onderzochte zeehonden vertegenwoordigen $~ 4 \%$ van de 406 dood gestrande zeehonden. Twee van de vijftien zeehonden (13\%) zijn waarschijnlijk overleden doordat ze in aanraking gekomen zijn met een voorwerp in het water. Daarnaast bleek een groot deel van de dieren waarschijnlijk aan longaandoeningen bezweken te zijn, terwijl ook een darmtorsie en darmperforatie werd waargenomen. Hoewel dit een waardevol eerste beeld geeft van mogelijke doodsoorzaken van zeehonden, is moeilijk in te schatten in hoeverre deze resultaten normaal zijn voor dood gestrande zeehonden. Er werden geen directe doodsoorzaken gevonden die te relateren waren met de verloren lading van de MSC ZOE.

3) Zijn er plastics gevonden in het verteringstelsel?

In geen van de vijftien zeehonden is plastics aangetroffen in het spijsverteringsstelsel dat als primair aangemerkt kon worden, dus dat gegeten is door een zeehond of wat een zeehond door het eten van vis binnen heeft gekregen. Bij drie van de vijftien dieren werden aanwijzingen gevonden van recent foerageren. Of er een relatie bestaat tussen het dieet en de aanwezigheid van plastics is in dit geval niet te zeggen. Maar de vissoorten, waarvan resten zijn gevonden in het spijsverteringsstelsel van de vijftien zeehonden, kunnen plastics bevatten (Tabel 5).

In deze studie is geen bewijs gevonden dat gewone of grijze zeehonden hinder hebben ondervonden van de verloren lading van de MSC ZOE. Omdat de resultaten wel duiden op een toename in het aantal dood gestrande zeehonden, is het aan te bevelen om in de nabije toekomst een nationale strandingsregistratie voor dood aangespoelde zeehonden op te zetten vergelijkbaar met de registratie van walvisachtigen (walvisstrandingen.nl). Hierbij kunnen eventuele duplicaten worden gecontroleerd, en een incomplete invoer worden aangevuld met informatie over bijvoorbeeld geslacht, soort, afmetingen en locatie. Met een dergelijk systeem kunnen vraagstukken, zoals effecten van incidenten zoals de MSC ZOE, betrouwbaarder en sneller getoetst worden. Bij een beter beeld van de sterfte van dieren kunnen ook structurele patronen duidelijk worden, zeker als bij een deel van de dood gevonden dieren ook de doodsoorzaak wordt onderzocht.

Om het effect van de MSC ZOE te kunnen in schatten is ook voor de komende jaren monitoring van het aantal strandingen nodig. Ook zal extra aandacht voor een mogelijke toename in het aantal verstrikte dieren moeten komen.

Aan te bevelen is om ook een monitoringsprogramma op te zetten waarbij jaarlijks de doodsoorzaak van zeehonden wordt onderzocht. Dit zal een kader geven van wat normale doodsoorzaken zijn van zeehonden. Daarnaast zal het de mogelijkheid bieden om nog grotere vraagstukken te beantwoorden bijvoorbeeld of afval in zee de overleving van de dieren beïnvloed, of hoe groot de bijvangst problematiek is bij zeehonden. Dit kan als urgent beschouwd worden, zeker in het licht van de afnemende gewone zeehondenpopulatie. Verder zijn zeehonden de talrijkste zeezoogdieren in de Waddenzee. Een goede monitoring van deze beschermde dieren is essentieel om effect rapportages te maken, zoals het effect van de verloren lading van de MSC ZOE. 


\section{$6 \quad$ Kwaliteitsborging}

Wageningen Marine Research beschikt over een ISO 9001:2015 gecertificeerd kwaliteitsmanagementsysteem. Dit certificaat is geldig tot vijftien december 2021. De organisatie is gecertificeerd sinds 27 februari 2001. De certificering is uitgevoerd door DNV GL.

Het chemisch laboratorium te IJmuiden beschikt over een NEN-EN-ISO/IEC 17025:2005 accreditatie voor testlaboratoria met nummer L097. Deze accreditatie is geldig tot 1 april 2021 en is voor het eerst verleend op 27 maart 1997; deze accreditatie is verleend door de Raad voor Accreditatie. Het chemisch laboratorium heeft hierdoor aangetoond in staat te zijn op technisch bekwame wijze valide resultaten te leveren en te werken volgens de ISO17025 norm. De scope (L097) met de geaccrediteerde analysemethoden is te vinden op de website van de Raad voor Accreditatie (www.rva.nl).

Op grond van deze accreditatie is het kwaliteitskenmerk $\mathrm{Q}$ toegekend aan de resultaten van die componenten die op de scope staan vermeld, mits aan alle kwaliteitseisen is voldaan. Het kwaliteitskenmerk Q staat vermeld in de tabellen met de onderzoeksresultaten. Indien het kwaliteitskenmerk $Q$ niet staat vermeld is de reden hiervan vermeld.

De kwaliteit van de analysemethoden wordt op verschillende manieren gewaarborgd. De juistheid van de analysemethoden wordt regelmatig getoetst door deelname aan ringonderzoeken waaronder die georganiseerd door QUASIMEME. Indien geen ringonderzoek voorhanden is, wordt een tweede lijnscontrole uitgevoerd. Tevens wordt bij iedere meetserie een eerstelijnscontrole uitgevoerd. Naast de lijnscontroles wordende volgende algemene kwaliteitscontroles uitgevoerd:

- Blanco onderzoek.

- Terugvinding (recovery).

- $\quad$ Interne standaard voor borging opwerkmethode.

- Injectie standard.

- Gevoeligheid.

Bovenstaande controles staan beschreven in Wageningen Marine Research werkvoorschrift ISW 2.10.2.105.

Indien gewenst kunnen gegevens met betrekking tot de prestatiekenmerken van de analysemethoden bij het chemisch laboratorium worden opgevraagd.

Indien sprake is van onbeheerste kwaliteit worden passende maatregelen genomen. 


\section{Literatuur}

Aarts, Geert M., Sophie M.J.M. Brasseur, Jan Jaap Poos, Jessica Schop, Roger Kirkwood, Tobias van Kooten, Evert Mul, Peter Reijnders, Adriaan D. Rijnsdorp, and Ingrid Tulp. 2019. "Top-down Pressure on a Coastal Ecosystem by Harbor Seals." Ecosphere 10 (1). https://doi.org/10.1002/ecs2.2538.

Anastasopoulou, Aikaterini, Manca Kovač Viršek, Dubravka Bojanić Varezić, Nikoletta Digka, Tomaso Fortibuoni, Špela Koren, Milica Mandić, et al. 2018. "Assessment on Marine Litter Ingested by Fish in the Adriatic and NE Ionian Sea Macro-Region (Mediterranean)." Marine Pollution Bulletin 133 (August): 841-51. https://doi.org/10.1016/j.marpolbul.2018.06.050.

Bessa, Filipa, Pablo Barría, João M. Neto, João P. G. L. Frias, Vanessa Otero, Paula Sobral, and João Carlos Marques. 2018. "Microplastics in Juvenile Commercial Fish from an Estuarine Environment." In Proceedings of the International Conference on Microplastic Pollution in the Mediterranean Sea, 13135. https://doi.org/10.1007/978-3-319-71279-6_18.

Bossart, Gregory D. 2011. "Marine Mammals as Sentinel Species for Oceans and Human Health." Veterinary Pathology 48 (3): 676-90. https://doi.org/10.1177/0300985810388525.

Brasseur, Sophie M.J.M. 2018. "Stranding and Rehabilitation in Numbers: Population Development and Stranding Data on the Dutch Coasts 1990-2016 : Analysis of New Data from a Public Database." https://doi.org/10.18174/440805.

Bravo Rebolledo, Elisa L., Jan Andries Van Franeker, Okka E. Jansen, and Sophie M.J.M. Brasseur. 2013. "Plastic Ingestion by Harbour Seals (Phoca Vitulina) in The Netherlands." Marine Pollution Bulletin 67 (1-2): 200-202. https://doi.org/10.1016/j.marpolbul.2012.11.035.

Browne, Mark A., Anthony J. Underwood, M. G. Chapman, Richard Williams, Richard C. Thompson, and Jan Andries Van Franeker. 2015. "Linking Effects of Anthropogenic Debris to Ecological Impacts." Proceedings of the Royal Society B: Biological Sciences 282 (1807): 20142929-20142929. https://doi.org/10.1098/rspb.2014.2929.

Camphuysen, Kees C.J., and Peter A. Henderson. 2017. North Sea Fish and Their Remains. Royal Netherlands Institute for Sea Research \& Pisces Conservation Ltd.

Carretta, James V, Van Helker, Marcia M Muto, Justin Greenman, Kristin Wilkinson, Dan Lawson, Justin Viezbicke, and Jason Jannot. 2018. "Sources of Human-Related Injury and Mortality for U.S. Pacific West Coast Marine Mammal Stock Assessments, 2012-2016." NOAA Technical Memorandum NMFS; NOAA-TM-NMFS-SWFSC; 601, no. June. https://doi.org/10.7289/V5/TM-SWFSC-601.

Cremer, Jenny S.M., Sophie M.J.M. Brasseur, Richard Czeck, Anders Galatius, Armin Jeß, Peter Körber, Ralf Pund, et al. 2019. "EG-Seals Grey Seal Surveys in the Wadden Sea and Helgoland in 2018-2019 Steady Growth," 1-5. http://www.waddensea-secretariat.org/sites/default/files/downloads/19-0701_greysealreport2019final.pdf.

Cremer, Jenny S.M., Sophie M.J.M. Brasseur, André Meijboom, Jessica Schop, and Hans J.P. Verdaat. 2017. "Monitoring van Gewone En Grijze Zeehonden in de Nederlandse Waddenzee, 2002-2017." https://doi.org/10.18174/428796.

Day, Robert H. 1988. "Quantitative Distribution and Characteristics of Neustonic Plastic in the North Pacific."

Derraik, José G.B. 2002. "The Pollution of the Marine Environment by Plastic Debris: A Review." Marine Pollution Bulletin 44 (9): 842-52. https://doi.org/10.1016/S0025-326X(02)00220-5.

Foekema, Edwin M., Corine De Gruijter, Mekuria T. Mergia, Jan Andries Van Franeker, Albertinka J. Murk, and Albert A. Koelmans. 2013. "Plastic in North Sea Fish." Environmental Science and Technology 47 (15): 8818-24. https://doi.org/10.1021/es400931b.

Fowler, C. W. 1988. "A Review of Seal and Sea Lion Entanglement in Marine Debris." Proceedings of the North Pacific Rim Fishermen's Conference on Marine Debris 1987, 16-63.

Franeker, Jan Andries Van, Elisa L. Bravo Rebolledo, Eileen Hesse, Lonneke L. Ijsseldijk, Susanne Kühn, Mardik Leopold, and Lara Mielke. 2018. "Plastic Ingestion by Harbour Porpoises Phocoena Phocoena in the Netherlands: Establishing a Standardised Method." Ambio 47 (4): 387-97. https://doi.org/10.1007/s13280-017-1002-y.

Galatius, Anders, Jenny S.M. Cremer, Richard Czeck, Armin Jeß, Peter Körber, Ralf Pund, Ursula Siebert, and Sascha Klöpper. 2018. "Aerial Surveys of Harbour Seals in the Wadden Sea in 2018 Another Record Year for Pups."

Härkönen, Tero. 1986. Guide to the Otoliths of the Bony Fishes of the Northeast Atlantic. Biological Consultants, Hellrup, Denmark.

Hipfner, J. Mark, Moira Galbraith, Strahan Tucker, Katharine R. Studholme, Alice D. Domalik, Scott F. Pearson, Thomas P. Good, Peter S. Ross, and Peter Hodum. 2018. "Two Forage Fishes as Potential Conduits for the Vertical Transfer of Microfibres in Northeastern Pacific Ocean Food Webs." 
Environmental Pollution 239 (August): 215-22. https://doi.org/10.1016/j.envpol.2018.04.009.

Hudak, Christine A., and Lisa Sette. 2019. "Opportunistic Detection of Anthropogenic Micro Debris in Harbor Seal (Phoca Vitulina Vitulina) and Gray Seal (Halichoerus Grypus Atlantica) Fecal Samples from HaulOuts in Southeastern Massachusetts, USA." Marine Pollution Bulletin 145 (February): 390-95. https://doi.org/10.1016/j.marpolbul.2019.06.020.

IJsseldijk, Lonneke L., and Judith M.A. Van den Brand. 2020. "Onderzoeksbevindingen van de Zeehonden Onderzocht in Het Kader van de MSC Zoë Vervuiling : Pathologie En Gezondheidsstatus."

Jepson, Paul D., Rob Deaville, Jonathan L. Barber, Àlex Aguilar, Asunción Borrell, Sinéad Murphy, Jon Barry, et al. 2016. "PCB Pollution Continues to Impact Populations of Orcas and Other Dolphins in European Waters." Scientific Reports 6 (January): 1-17. https://doi.org/10.1038/srep18573.

Johnston, David W., Jaime Frungillo, Ainsley Smith, Katie Moore, Brian Sharp, Janelle Schuh, and Andrew J. Read. 2015. "Trends in Stranding and By-Catch Rates of Gray and Harbor Seals along the Northeastern Coast of the United States: Evidence of Divergence in the Abundance of Two Sympatric Phocid Species?" PLOS ONE 10 (7): 1-12. https://doi.org/10.1371/journal.pone.0131660.

Kartar, S., F. Abou-Seedo, and M. Sainsbury. 1976. "Polystyrene Spherules in the Severn Estuary - A Progress Report." Marine Pollution Bulletin 7 (3): 52. https://doi.org/1016/0025-326X(76)90092-8.

Kartar, S, R.A Milne, and M Sainsbury. 1973. "Polystyrene Waste in the Severn Estuary." Marine Pollution Bulletin 4 (9): 144. https://doi.org/10.1016/0025-326X(73)90010-6.

Kühn, Susanne, Elisa L. Bravo Rebolledo, and Jan Andries Van Franeker. 2015. "Preface." Edited by Melanie Bergmann, Lars Gutow, and Michael Klages. Deleterious Effects of Litter on Marine Life, 75-116. https://doi.org/10.1007/978-3-319-16510-3.

Kühn, Susanne, and Jan Andries Van Franeker. 2020. "Quantitative Overview of Marine Debris Ingested by Marine Megafauna." Marine Pollution Bulletin 151 (January): 110858. https://doi.org/10.1016/j.marpolbul.2019.110858.

Kühn, Susanne, Jan Andries Van Franeker, Anastasia M. O’Donoghue, Ailynn Swiers, Marrit Starkenburg, Bernike van Werven, Edwin Foekema, Enya Hermsen, Marion Egelkraut-Holtus, and Han Lindeboom. 2020. "Details of Plastic Ingestion and Fibre Contamination in North Sea Fishes." Environmental Pollution. https://doi.org/10.1016/j.envpol.2019.113569.

Laist, David W. 1997. Impacts of Marine Debris: Entanglement of Marine Life in Marine Debris Including a Comprehensive List of Species with Entanglement and Ingestion Records. Coe, J.M., Rogers, D.B. (Eds.), Marine Debris: Sources, Impacts, and Solutions, Springer New York, New York, NY.

López-López, Lucía, Izaskun Preciado, José Manuel González-Irusta, Nina Larissa Arroyo, Isabel Muñoz, Antonio Punzón, and Alberto Serrano. 2018. "Incidental Ingestion of Meso- and Macro-Plastic Debris by Benthic and Demersal Fish." Food Webs 14 (March): 1-4. https://doi.org/10.1016/j.fooweb.2017.12.002.

Lusher, Amy L., Matthew McHugh, and Richard C. Thompson. 2013. "Occurrence of Microplastics in the Gastrointestinal Tract of Pelagic and Demersal Fish from the English Channel." Marine Pollution Bulletin 67 (1-2): 94-99. https://doi.org/10.1016/j.marpolbul.2012.11.028.

McGoran, Alexandra R., Paul F. Clark, and D. Morritt. 2017. "Presence of Microplastic in the Digestive Tracts of European Flounder, Platichthys Flesus, and European Smelt, Osmerus Eperlanus, from the River Thames." Environmental Pollution 220 (January): 744-51. https://doi.org/10.1016/j.envpol.2016.09.078.

McGoran, Alexandra R., Phillip R. Cowie, Paul F. Clark, James P. McEvoy, and David Morritt. 2018. "Ingestion of Plastic by Fish: A Comparison of Thames Estuary and Firth of Clyde Populations." Marine Pollution Bulletin 137 (December): 12-23. https://doi.org/10.1016/j.marpolbul.2018.09.054.

Moore, Charles J., Shelly L. Moore, Molly K. Leecaster, and Stephen B. Weisberg. 2001. "A Comparison of Plastic and Plankton in the North Pacific Central Gyre." Marine Pollution Bulletin 42 (12): 1297-1300. https://doi.org/10.1016/S0025-326X(01)00114-X.

Murphy, Fionn, Marie Russell, Ciaran Ewins, and Brian Quinn. 2017. "The Uptake of Macroplastic \&amp; Microplastic by Demersal \&amp; Pelagic Fish in the Northeast Atlantic around Scotland." Marine Pollution Bulletin 122 (1-2): 353-59. https://doi.org/10.1016/j.marpolbul.2017.06.073.

Nelms, Sarah E., James Barnett, Andrew Brownlow, N.J. Davison, Rob Deaville, Tamara S. Galloway, Penelope K. Lindeque, D. Santillo, and Brendan J. Godley. 2019. "Microplastics in Marine Mammals Stranded around the British Coast: Ubiquitous but Transitory?" Scientific Reports 9 (1): 1-8. https://doi.org/10.1038/s41598-018-37428-3.

Nelms, Sarah E., Tamara S. Galloway, Brendan J. Godley, Dan S. Jarvis, and Penelope K. Lindeque. 2018. "Investigating Microplastic Trophic Transfer in Marine Top Predators." Environmental Pollution 238: 999-1007. https://doi.org/10.1016/j.envpol.2018.02.016.

Osinga, Nynke. 2006. "Fish-Hook Ingestion in Seals (Phoca Vitulina and Halichoerus Grypus): The Scale of the Problem and a Non-Invasive Method for Removing Fish-Hooks." Aquatic Mammals 32 (2): 261-64.

Pellini, Giulio, Alessio Gomiero, Tomaso Fortibuoni, Carmen Ferrà, Fabio Grati, Anna Nora Tassetti, Piero Polidori, Gianna Fabi, and Giuseppe Scarcella. 2018. "Characterization of Microplastic Litter in the 
Gastrointestinal Tract of Solea Solea from the Adriatic Sea." Environmental Pollution 234 (March): 943-52. https://doi.org/10.1016/j.envpol.2017.12.038.

Peltier, Helene, Hans J. Baagøe, Kees C.J. Camphuysen, Richard Czeck, Willy Dabin, Pierre Daniel, Rob Deaville, et al. 2013. "The Stranding Anomaly as Population Indicator: The Case of Harbour Porpoise Phocoena Phocoena in North-Western Europe." PLOS ONE 8 (4). https://doi.org/10.1371/journal.pone.0062180.

Pierce, Graham J., Maria B. Santos, Sinead Murphy, Jennifer A. Learmonth, Alan F. Zuur, Emer Rogan, Paco Bustamante, et al. 2008. "Bioaccumulation of Persistent Organic Pollutants in Female Common Dolphins (Delphinus Delphis) and Harbour Porpoises (Phocoena Phocoena) from Western European Seas: Geographical Trends, Causal Factors and Effects on Reproduction and Mortality." Environmental Pollution 153 (2): 401-15. https://doi.org/10.1016/j.envpol.2007.08.019.

Rummel, Christoph D., Martin G.J. Löder, Nicolai F. Fricke, Thomas Lang, Eva-Maria Griebeler, Michael Janke, and Gunnar Gerdts. 2016. "Plastic Ingestion by Pelagic and Demersal Fish from the North Sea and Baltic Sea." Marine Pollution Bulletin 102 (1): 134-41. https://doi.org/10.1016/j.marpolbul.2015.11.043.

Shomura, Richard S., and Howard O. Yoshida. 1985. "Proceedngs of the Workshop on the Fate and Impact of Marine Debris." NOAA Technical Memorandum NMFS, no. November 1984: 574.

Soulen, Brianne K., Kristina Cammen, Thomas F. Schultz, and David W. Johnston. 2013. "Factors Affecting Harp Seal (Pagophilus Groenlandicus) Strandings in the Northwest Atlantic." PLoS ONE 8 (7). https://doi.org/10.1371/journal.pone.0068779.

Steer, Madeleine, Matthew Cole, Richard C. Thompson, and Penelope K. Lindeque. 2017. "Microplastic Ingestion in Fish Larvae in the Western English Channel." Environmental Pollution 226 (July): 250-59. https://doi.org/10.1016/j.envpol.2017.03.062.

Watt, J., Graham J. Pierce, and P.R. Boyle. 1997. "Guide to the Identification of North Sea Fish Using Premaxillae and Vertebrae."

Welden, Natalie A.C., Bexultan Abylkhani, and Leigh Michael Howarth. 2018. "The Effects of Trophic Transfer and Environmental Factors on Microplastic Uptake by Plaice, Pleuronectes Plastessa, and Spider Crab, Maja Squinado." Environmental Pollution 239 (August): 351-58. https://doi.org/10.1016/j.envpol.2018.03.110. 


\section{Verantwoording}

Rapport: C043/20

Projectnummer: BO-43-023.02-039-WMR

Dit rapport is met grote zorgvuldigheid tot stand gekomen. De wetenschappelijke kwaliteit is intern getoetst door een collega-onderzoeker en het verantwoordelijk lid van het managementteam van Wageningen Marine Research

Akkoord:

Ir. S.C.V. Geelhoed

Onderzoeker

Handtekening:

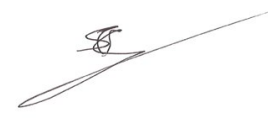

Datum: $\quad 8$ mei 2020

Akkoord: Dr. J. Asjes

Manager Integratie

Handtekening:

Datum:

8 mei 2020 


\section{Bijlage 1 Foto's gestrande zeehonden}

Deze foto's horen bij het rapport van IJsseldijk en Brand (2020) en zijn per zeehondennummer (zie ook Tabel 2) weergegeven.

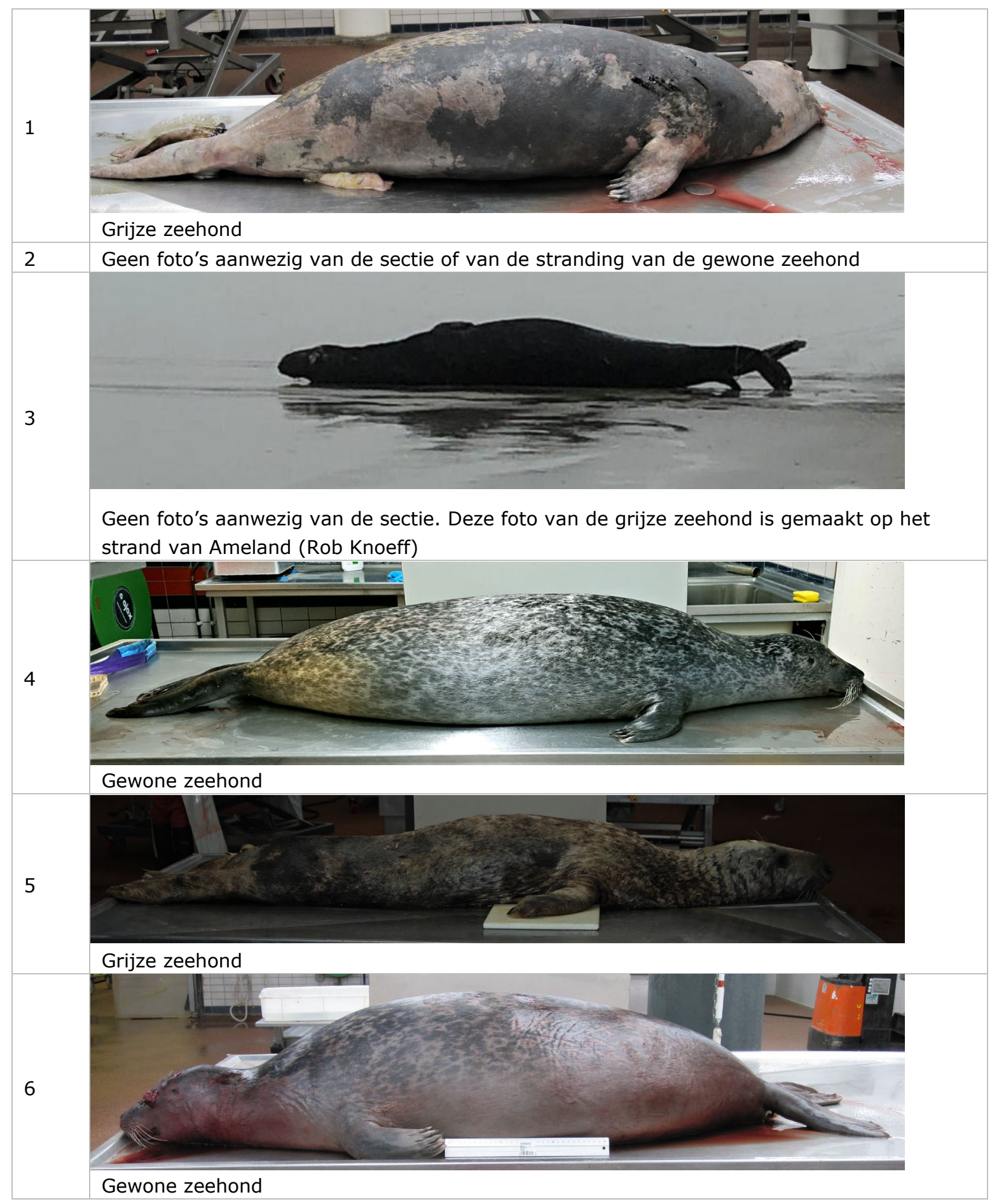


6.1

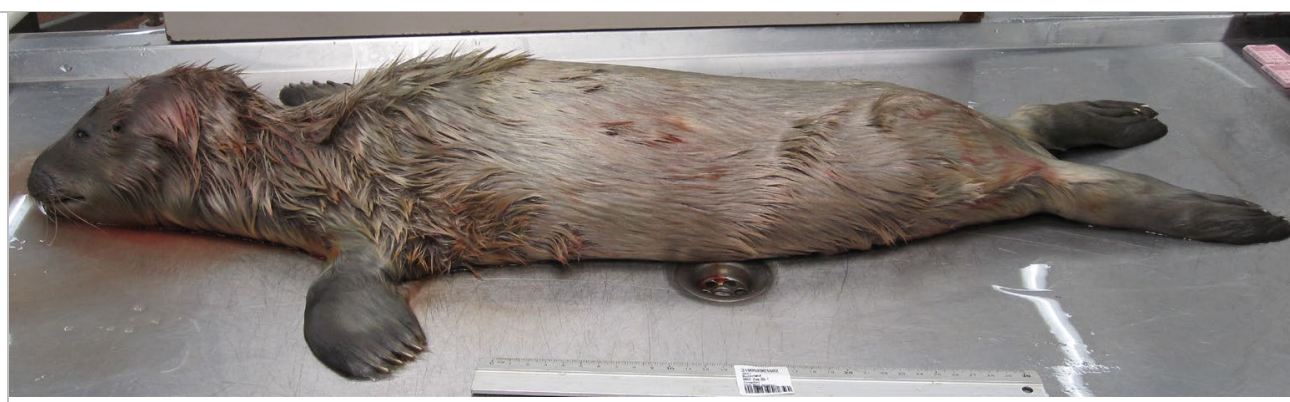

Gewone zeehond (foetus)

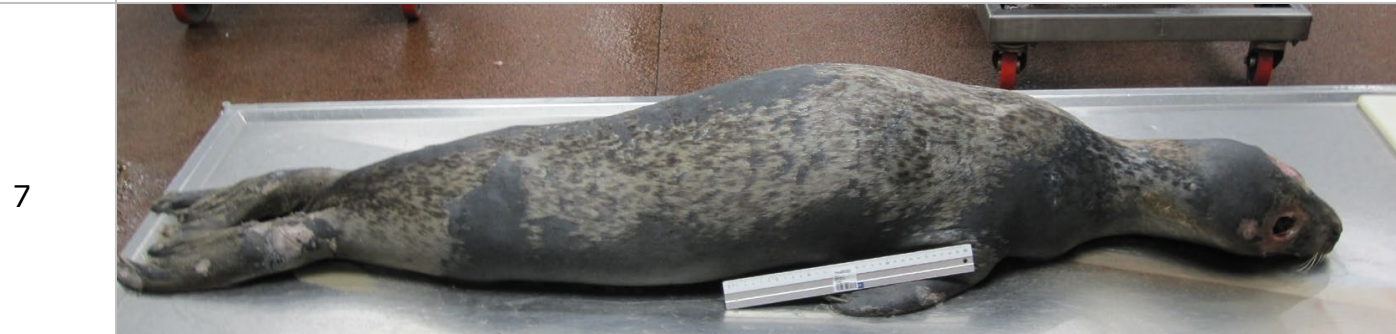

\section{Grijze zeehond}

8

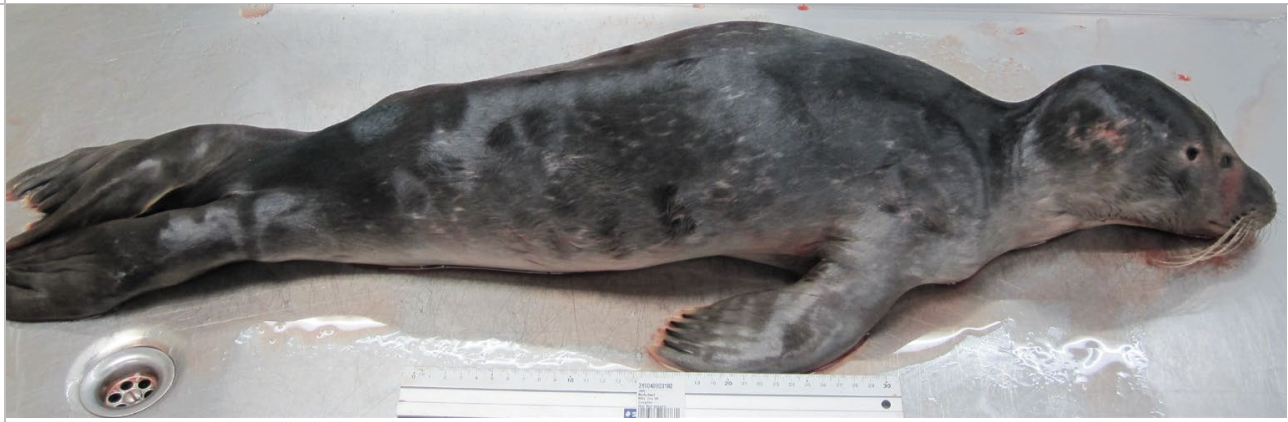

\section{Gewone zeehond}

9

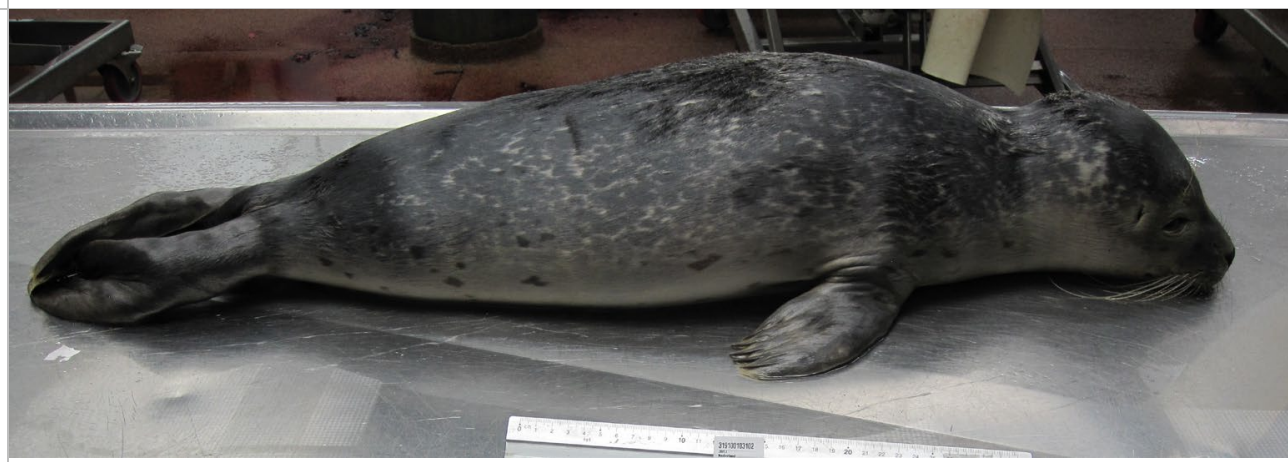

Gewone zeehond

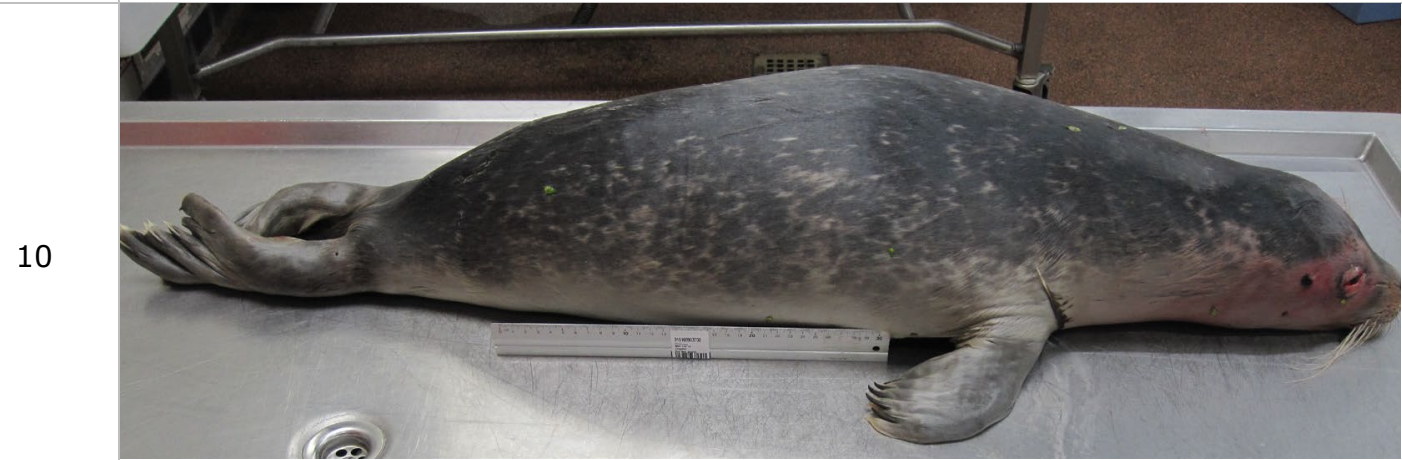

Gewone zeehond 


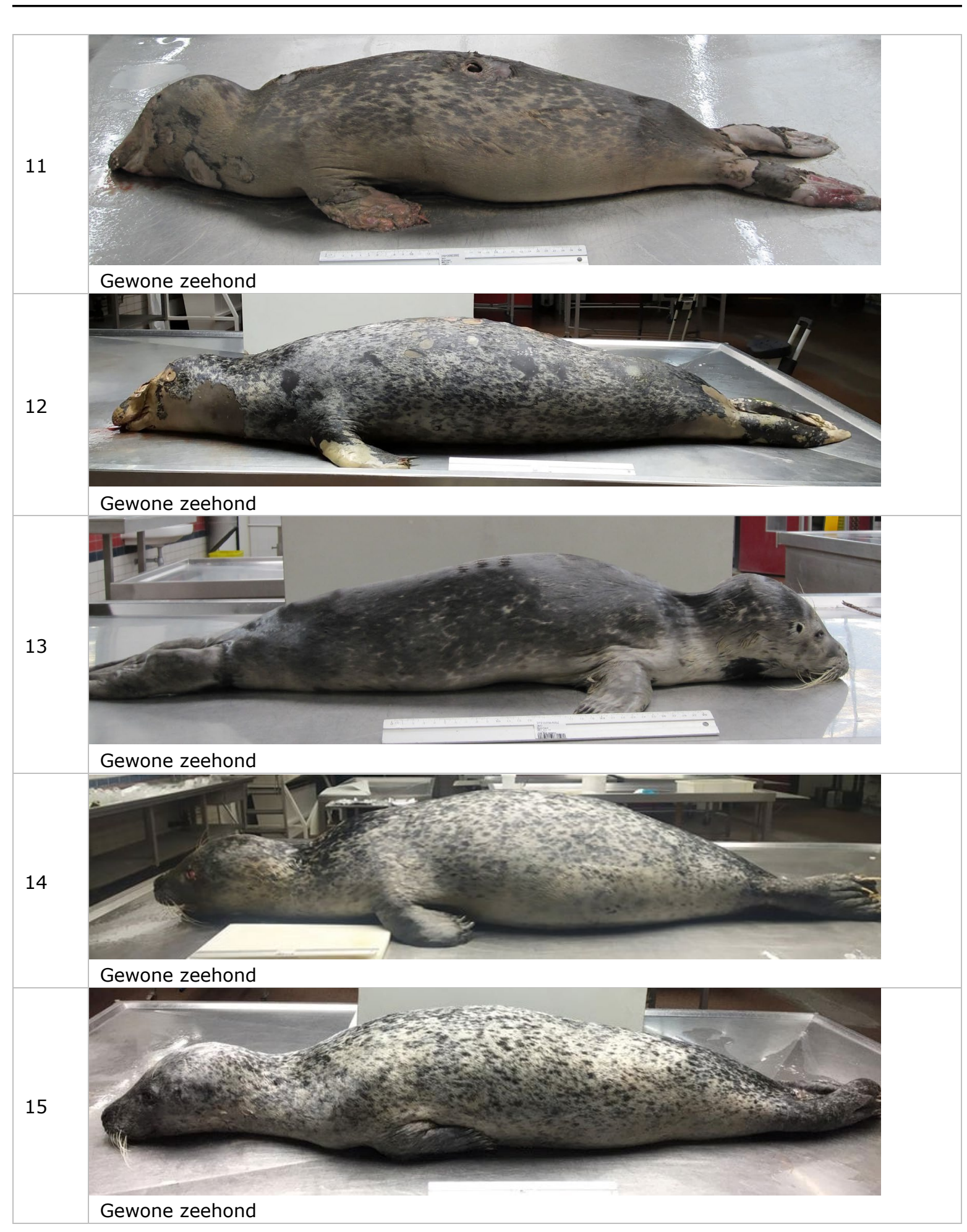


Wageningen Marine Research

T: +31(0)317480900

E: marine-research@wur.nl

www.wur.nl/marine-research

Bezoekers adres:

- Ankerpark 271781 AG Den Helder

- Korringaweg 7, 4401 NT Yerseke

- Haringkade 1, 1976 CP IJmuiden
Wageningen Marine Research levert met kennis, onafhankelijk wetenschappelijk onderzoek en advies een wezenlijke bijdrage aan een duurzamer, zorgvuldiger beheer, gebruik en bescherming van de natuurlijke rijkdommen in zee-, kust- en zoetwatergebieden.
Wageningen Marine Research is onderdeel van Wageningen University \& Research. Wageningen University \& Research is het samenwerkingsverband tussen Wageningen University en Stichting Wageningen Research en heeft als missie: 'To explore the potential of nature to improve the quality of life' 